\title{
11. SITE SURVEYS (DRILL SITES 155 AND 158) ON THE COIBA AND COCOS RIDGES IN THE PANAMA BASIN ${ }^{1}$
}

\author{
Marek Truchan and Thomas Aitken, Lamont-Doherty Geological Observatory, Columbia University, \\ Palisades, New York
}

\begin{abstract}
A seismic reflection profiler and $3.5-\mathrm{kHz}$ high-resolution echo sounder survey were used to map the sediment distribution, establish the seismic stratigraphy, and examine the sea floor morphology and shallow subbottom structures at the two sites.
\end{abstract}

\section{INTRODUCTION}

Early in 1971, Sites DSDP 155 and 158 were surveyed by the R.V. Vema during Leg 9 (Cristobal, Panama, to Acapulco, Mexico) of Cruise 28 before they were drilled (van Andel et al., 1971b) (Table 1). One reason these sites were selected was to test the hypothesis (van Andel et al., 1971a) that the Cocos, Coiba, and other blocks scattered throughout the Panama Basin (Figure 1) were once part of an ancestral Carnegie Ridge which parted during the late Miocene due to the formation of the Galapagos Rift Zone. These fragments then migrated to the north, sealing the Middle America Trench. The present subduction zone now terminates against the western edge of the Cocos Ridge. for Station 148 on Coiba Ridge, then continued on course $219^{\circ} \mathrm{T}$, passing close to the drill site (Figure 6). Upon completion of the site survey, the ship exited from the region on course $305^{\circ} \mathrm{T}$, traversing the Coiba (Panama) Fracture Zone ${ }^{2}$ (Figure 1) and occupied Station 151 at the foot of the Cocos escarpment (Profiles 1117-1118, Plate 2). A complete traverse of the ridge was then made on $270^{\circ} \mathrm{T}$ to the western basin, where course was changed to $145^{\circ} \mathrm{T}$ (at $0900 \mathrm{hrs}$., Figure 1) to head back for the ridge. Station 152 was located at the base of the ridge (Profiles 1126-1127, Plate 2). The R.V. Vema then proceeded to Site DSDP 158 on course $145^{\circ} \mathrm{T}$, passing close to the site (Figure 14). The survey ended with Profile 1151 (Plate 3), exiting from the area on course $145^{\circ} \mathrm{T}$ (Figure 15).

TABLE 1

A List of the Stations Occupied by the R.V.Vema During

Cruise 28, Leg 9, While Surveying Sites DSDP 155 and 158

\begin{tabular}{|c|c|c|c|c|c|c|c|c|}
\hline \multirow[b]{2}{*}{ Station } & \multicolumn{4}{|c|}{ Coiba Ridge } & \multicolumn{4}{|c|}{ Cocos Ridge } \\
\hline & 148 & 149 & 150 & 151 & 152 & 153 & 154 & 155 \\
\hline Position & $\begin{array}{l}06^{\circ} 14^{\prime} \\
80^{\circ} 53^{\prime}\end{array}$ & $\begin{array}{l}06^{\circ} 32^{\prime} \\
81^{\circ} 18^{\prime}\end{array}$ & $\begin{array}{l}06^{\circ} 09^{\prime} \\
80^{\circ} 53^{\prime}\end{array}$ & $\begin{array}{l}07^{\circ} 31^{\prime} \\
82^{\circ} 51^{\prime}\end{array}$ & $\begin{array}{l}06^{\circ} 54^{\prime} \\
85^{\circ} 26^{\prime}\end{array}$ & $\begin{array}{l}06^{\circ} 05^{\prime} \\
85^{\circ} 16^{\prime}\end{array}$ & $\begin{array}{l}06^{\circ} 19^{\prime} \\
84^{\circ} 16^{\prime}\end{array}$ & $\begin{array}{l}06^{\circ} 35^{\prime} \\
85^{\circ} 19\end{array}$ \\
\hline Core & 130 & 131 & 132 & 133 & 134 & 135 & $\begin{array}{l}136 \\
137\end{array}$ & 138 \\
\hline T Grad & - & 61 & 62 & 63 & - & - & - & 64 \\
\hline Camera & 79 & 80 & 81 & 82 & 83 & 84 & 85 & 86 \\
\hline $\begin{array}{l}\text { Core head } \\
\text { camera }\end{array}$ & - & - & - & - & 22 & 23 & 24 & 25 \\
\hline Nephelometer & 93 & 94 & 95 & 96 & 97 & 98 & 99 & 100 \\
\hline $\begin{array}{l}\text { Current } \\
\text { meter }\end{array}$ & 57 & 58 & 59 & 60 & 61 & 62 & 63 & 64 \\
\hline
\end{tabular}

\section{TRACK SYNPOSIS}

After leaving the Panamanian continental shelf the R.V. Vema altered course to the southwest, traversed a marginal trough (0940-1030 hrs., Figures 1, 1.6), stopped

\footnotetext{
${ }^{1}$ The fracture zone between $82^{\circ}-83^{\circ} \mathrm{W}$ has been named Panama Fracture Zone by Molnar and Sykes (1969) and this term was later used by Grim (1970). van Andel et al. (1971a) proposéd to call it Coiba Fracture Zone. In order to avoid internal inconsistency in this volume, we shall refer to it as Coiba Fracture Zone.
}

\section{COIBA RIDGE (DSDP 155)}

The location of the drill site (Figures 2, 3 ) in relation to the rest of the ridge may be readily envisioned with the aid of Figure 4, which illustrates the description: "The Coiba Ridge is a large eastward-sloping slab with its high western edge uplifted along one of the faults of the Coiba fracture zone." (van Andel et al., 1971a, p. 1497). The ridge thus appears tilted about a basement "hinge" near the 2100-hour location, beneath a sedimentary escarpment (see Figure 5 for a closeup of the scarp) which trends 


\section{TRUCHAN, T. AITKEN}

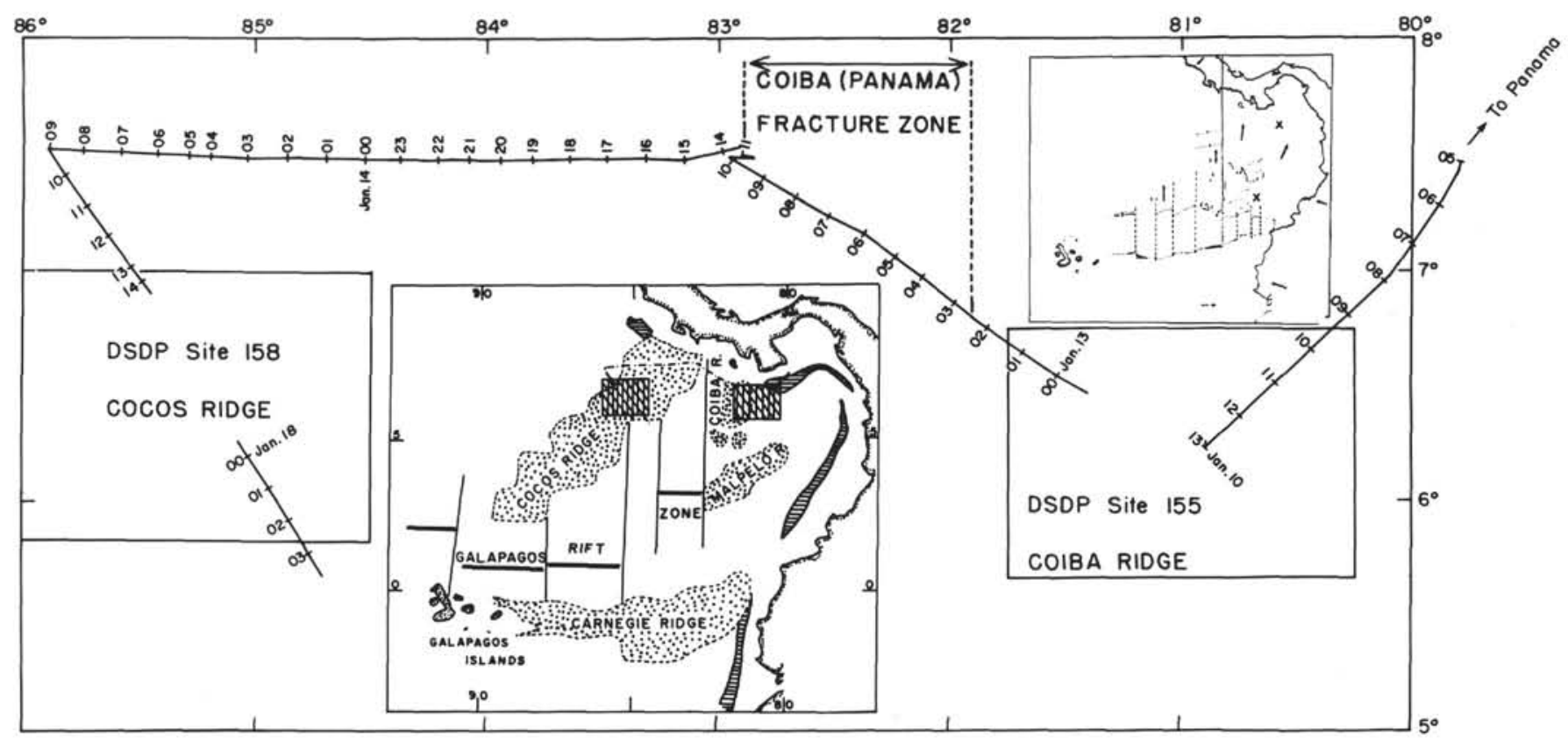

Figure 1. Track of the R.V. Vema to and between the site surveys (Figures 2, 3, 12, 13). The hourly positions are keyed to figures and plates. Profiler data across the Coiba Fracture Zone are presented in Figure 11, and those corresponding to the east-west traverse of the Cocos Ridge north of DSDP 158 are covered by Profiles 1118-1123, Plate 2. The relation of the two surveys quadrangles to the major topographic features of the Panama Basin is indicated in the largest inset (simplified from van Andel et al., 1971a, p.1490), and the hypothesized evolution of the basin is demonstrated in the smaller one (from van Andel et al., 1971a, p. 1505).

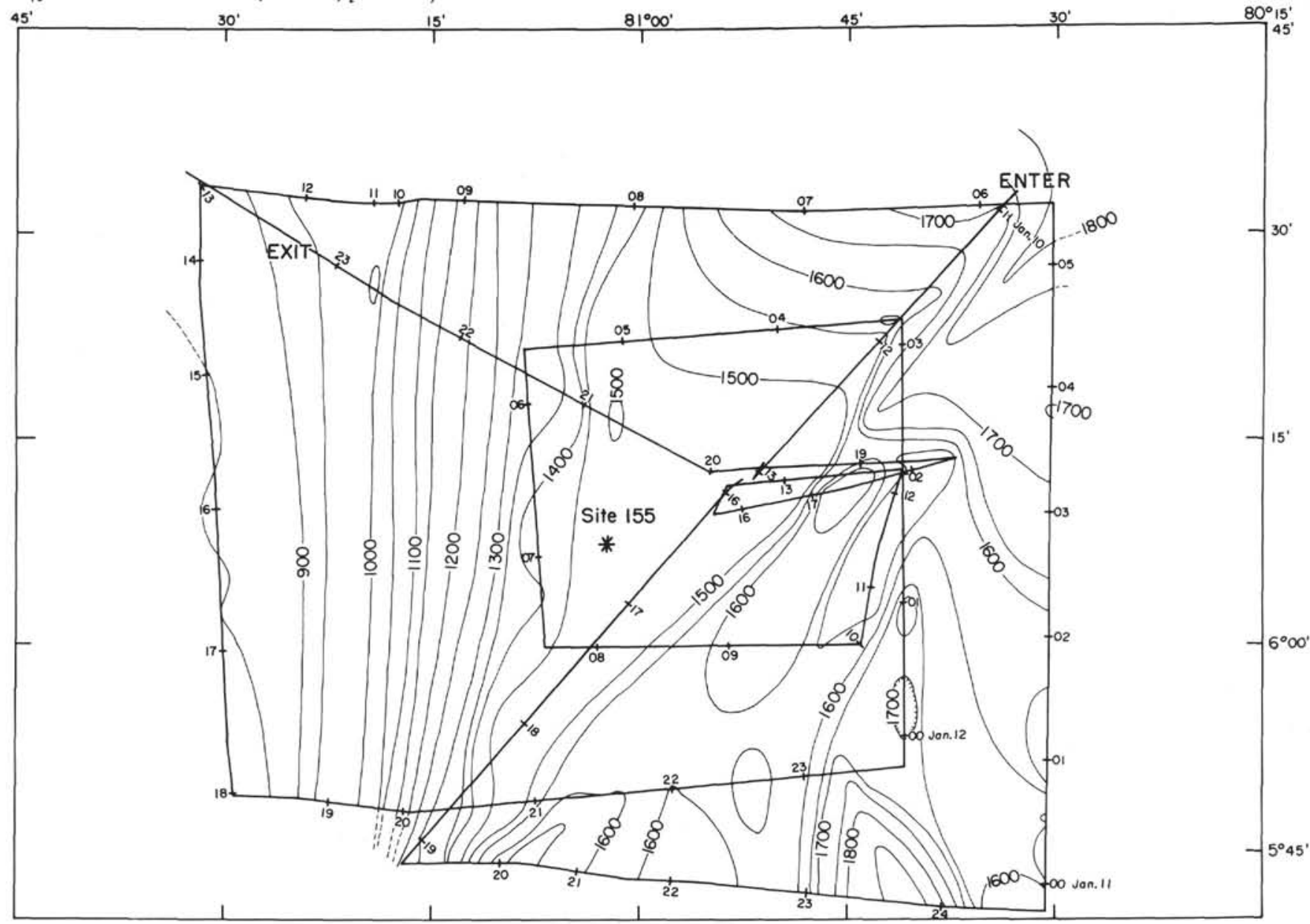

Figure 2. Bathymetric map of Site DSDP 155 survey contoured in nominal fathoms at 50-fm contour interval. 


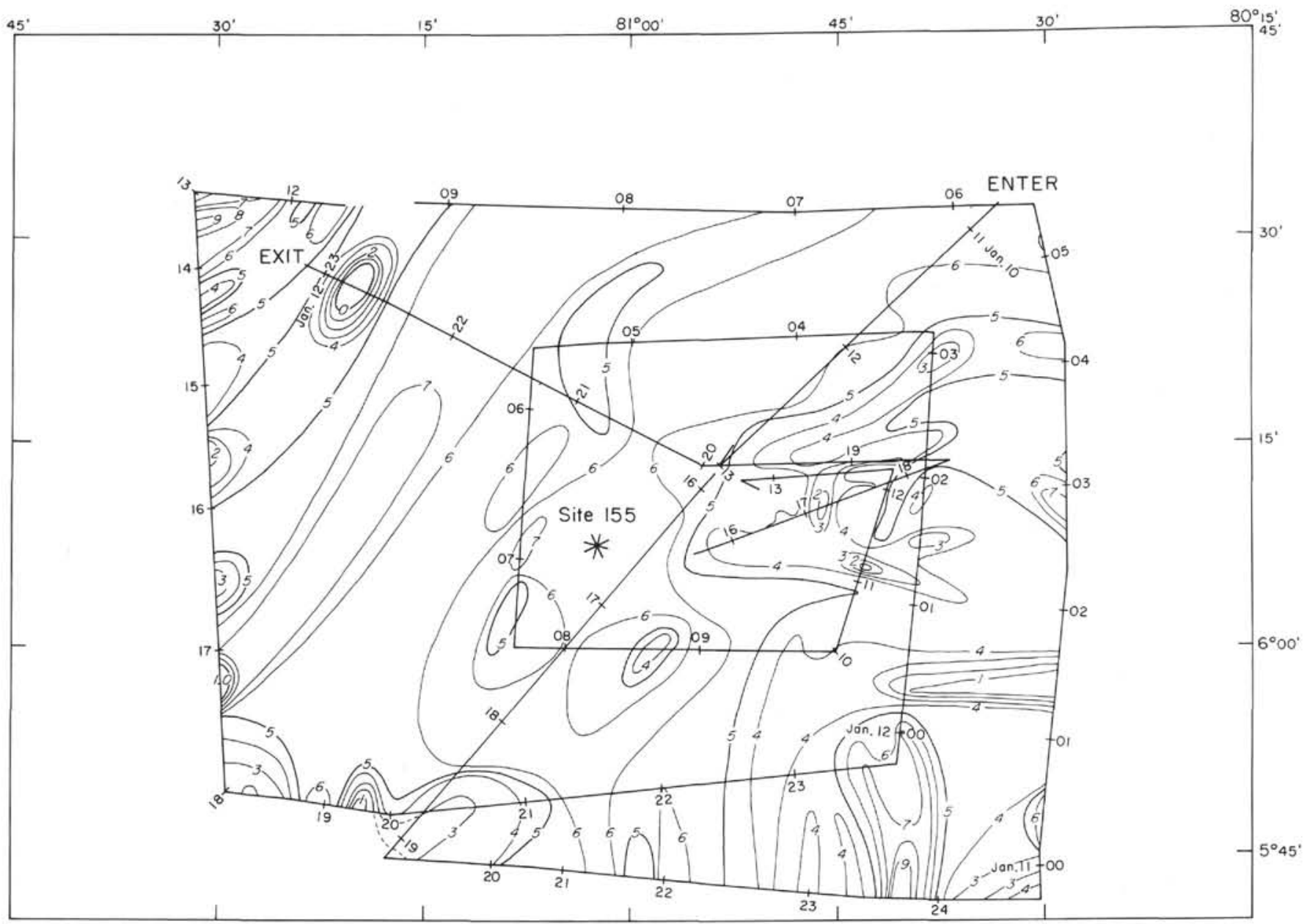

Figure 3. Sediment thickness map of Site DSDP 155 survey contoured in tenths of seconds of two-way reflection time. The map is based on reflection time readings at 10-minute intervals. This region is covered by Profiles 1095-1114 (Plate 1).

northeast-southwest across the entire survey area as indicated by the bathymetric contours (Figure 2). DSDP 155 lies just east of this fault, mapped by van Andel et al. (1971a), in a region of level sea floor characterized by short-wave-length undulations which can be followed on the $3.5-\mathrm{kHz}$ fathogram to almost 100 meters below the bottom (Figure 6). The acoustic character of the section is typical for the whole region, and even the sea floor remains "rippled" in most of the area, with the exception of the shallower regions. Although the overall appearance of the profiler section shown in Figure 6 may be described as somewhat fuzzy, stratification does exist see (Figure 9).

The isopach map (Figure 3) shows that the sediment cover is rather uniform, ranging from about $0.4-0.6$ second reflection time. The more complicated pattern of sediment distribution east of the drill site probably reflects the complexity of the fault system mapped by van Andel et al. (1971a). An example of recent tectonic activity is shown in Figure 7. Such examples are lacking elsewhere, but the presence of faults may be inferred from sediment scarps such as the one in Figure 5. The other irregularities on the isopach map, notably along the westernmost track and the southwest corner, are probably due to sediment removal by bottom currents. This is the shallowest part of the ridge, and it is here that stretches of smooth instead of undulating bottom found elsewhere are present. The increasing competence of bottom currents to erode, with decreasing depth, is well illustrated in Figure 4. This figure shows the gradual smoothing of the sea floor along the interval 2200-2300 hours. Note the scoured moat around the outcropping basement peak at 2245 hours. Upslope from the peak, only smooth sea floor is present and the $3.5-\mathrm{kHz}$ fathograms show near-surface beveling of seismic horizons. On the crest, most of the sediment cover has apparently been removed, but some must still be present, judging from the subtle stratification discernable on the peak at 0110 hours. A good example of erosion on the upper portion of the tilted Coiba slab is shown in Plate 1, (1900 hrs., Jan. 10), and the most spectacular one in the whole region is presented in Figure 7. On the ridge flank, evidence for bottom currents consists of moated, outcropping basement peaks and channel-like cross sections at the foot of scarps (Plate 1), where it is reasonable to expect current acceleration. Bottom currents capable of such performance have not been measured at any of the tripod (instrument described in Thorndike and Ewing, 1969) stations on the ridge, however, nor can they be inferred from the simultaneously obtained photographs of the sea floor. Only weak currents (less than $4 \mathrm{~cm} / \mathrm{sec}$ ) have been recorded, but they are apparently sufficiently fast to bend some of the sea pens (Figure 8). 


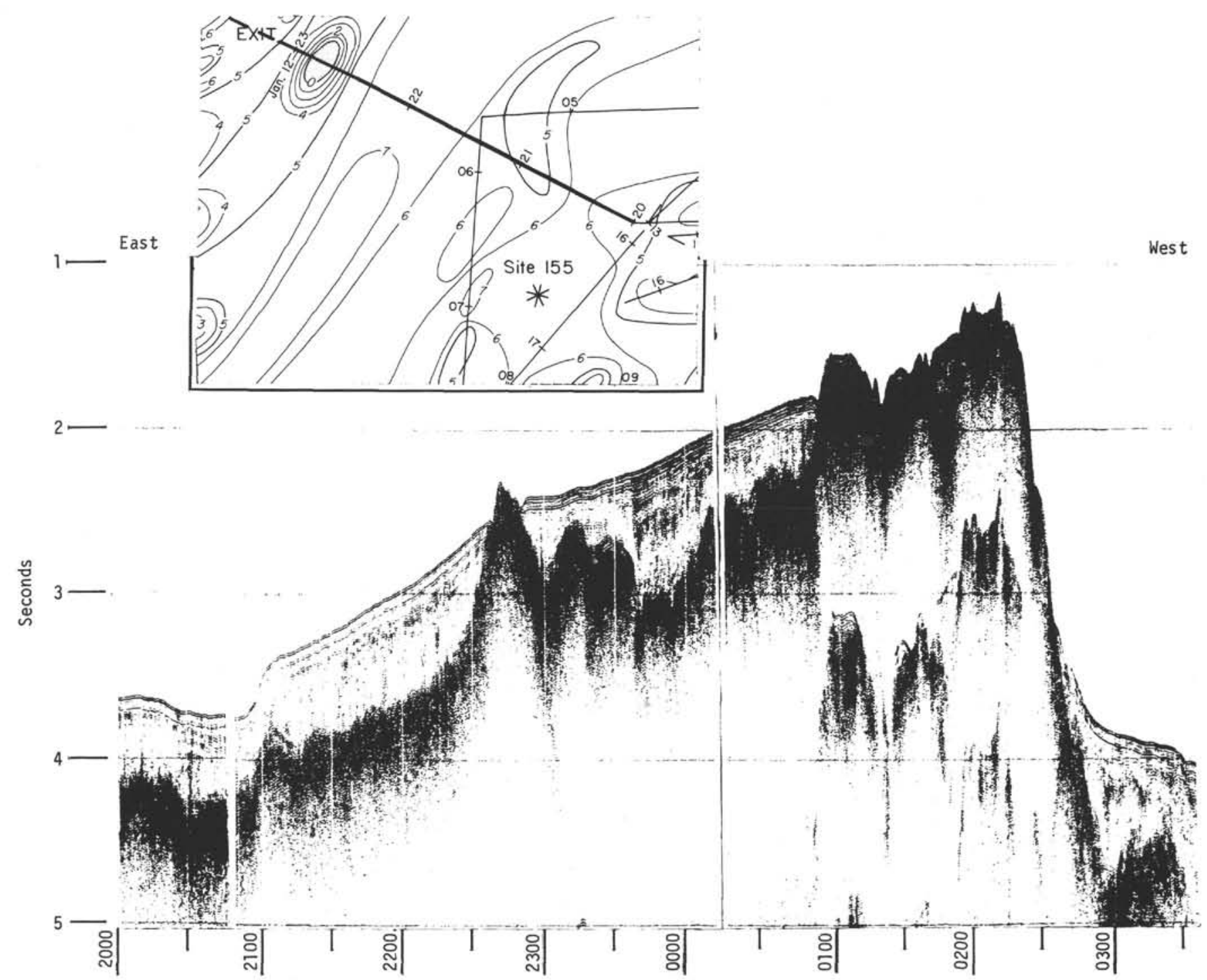

Figure 4. A profiler section of the uptilted Coiba block, extending from the eastern flank of the ridge to the Coiba Fracture Zone. Note that the seismic stratigraphy continues unchanged across the fault scarp at 2100 hours and even the sea floor remains "rippled." The onset of smooth bottom upslope of the outcropping basement at 2245 hours and the absence of sediments on the crest of the ridge indicate an increasing role of bottom currents in the shallower regions. Note that the basement peak at 0110 hours appears to be stratified. The sediment "meniscus" at the foot of the high western face of the Coiba Ridge suggests that these sediments have been swept from the crestal region. This section is covered by Profiles 1113-1115, Plates 1 and 2. 


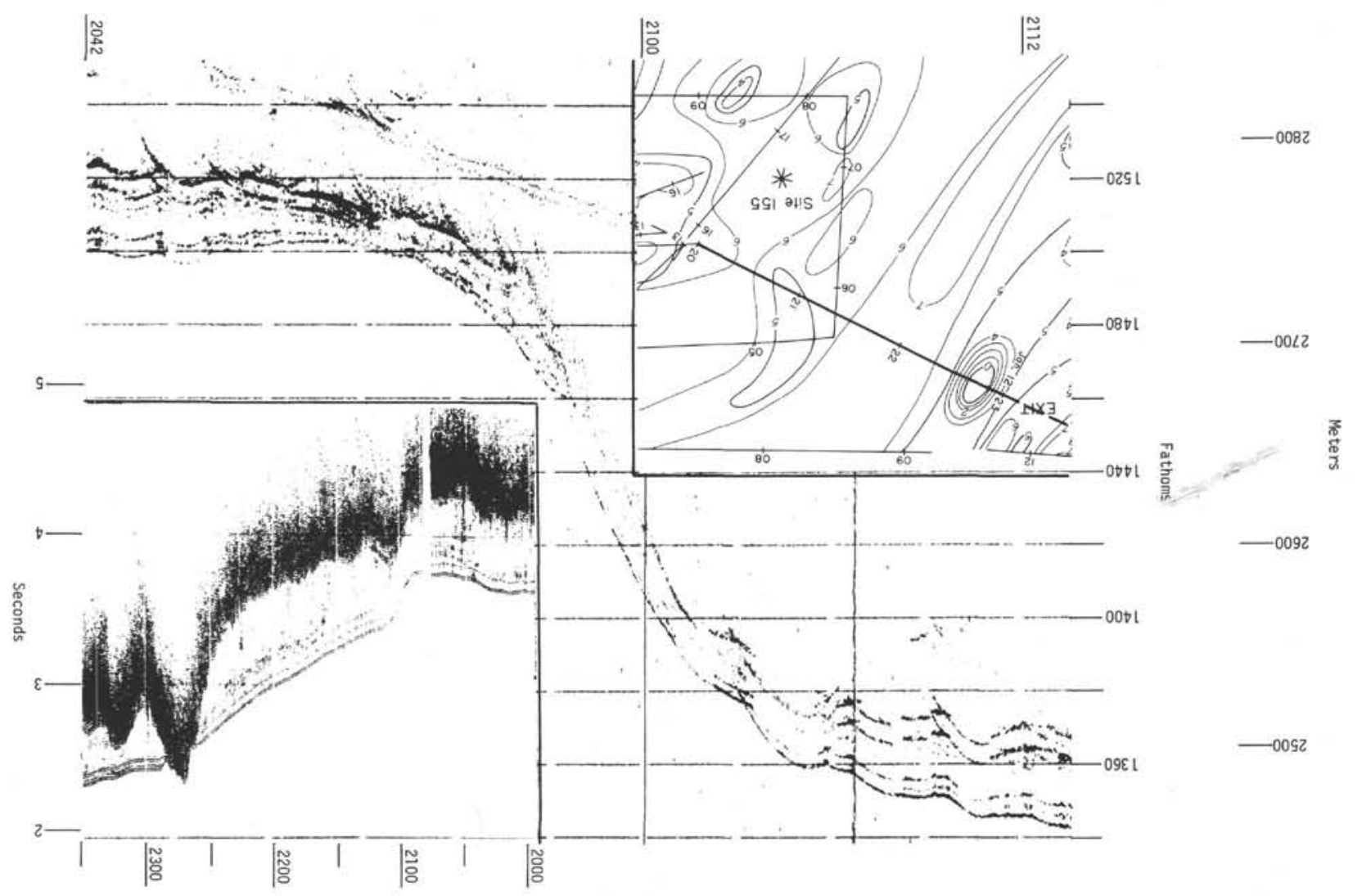

Figure 5. A 3.5-kHz fathogram and seismic reflection record (Profiles 1113-1114, Plate 1) across one of the major north-south trending faults mapped by van Andel et al., 1971a. 


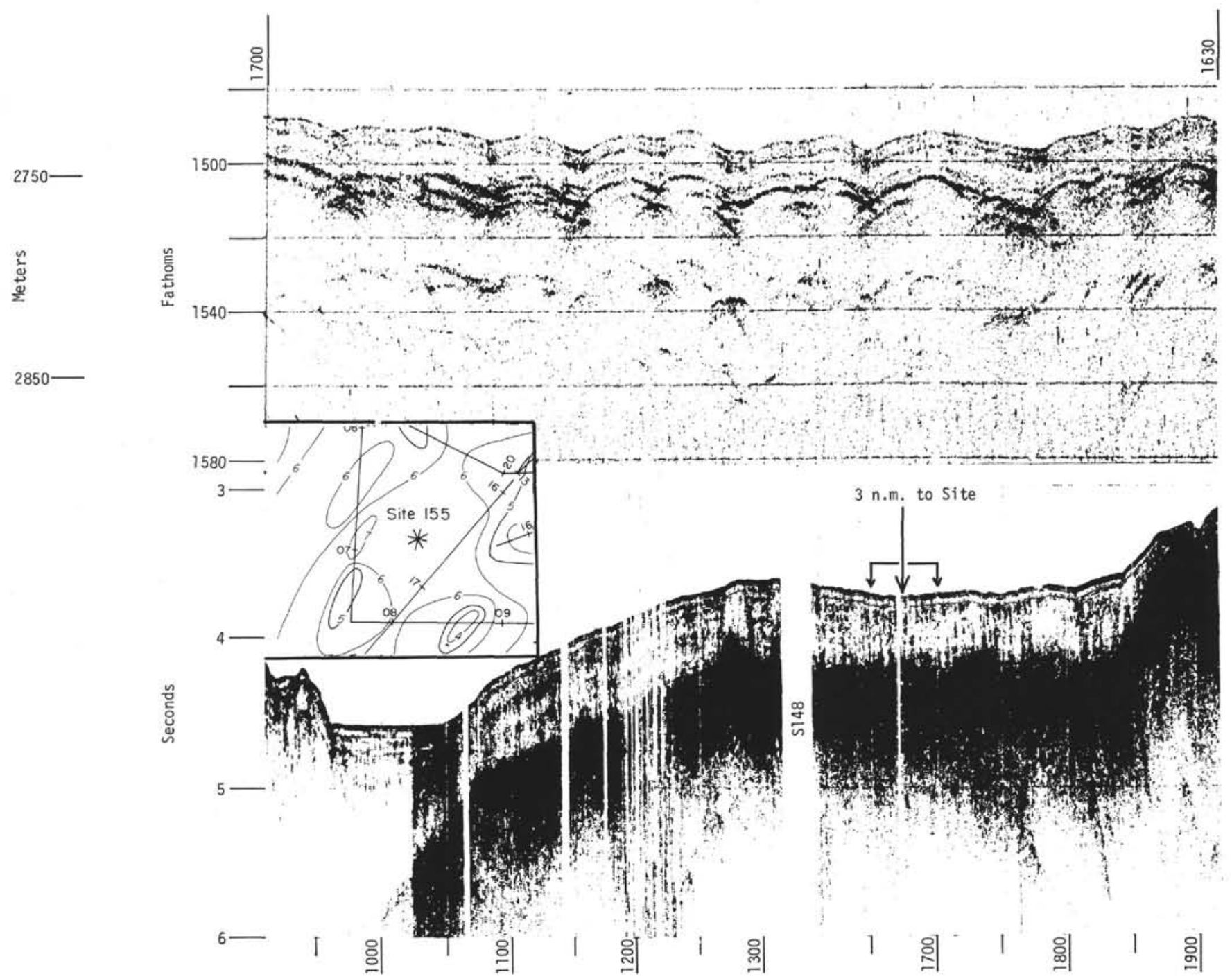

Figure 6. A 3.5-kHz and profiler section across the eastern flank of the Coiba Ridge near the drill site. The seismic stratigraphy as well as the "rippled" sea floor are typical for most of the region. The Panamanian marginal trough is on the left, centered at 1000 hours. See Figure 1 for location. A 3.5-kHz fathogram of the peak on the right (1900 hrs.) is shown in Figure 7. 


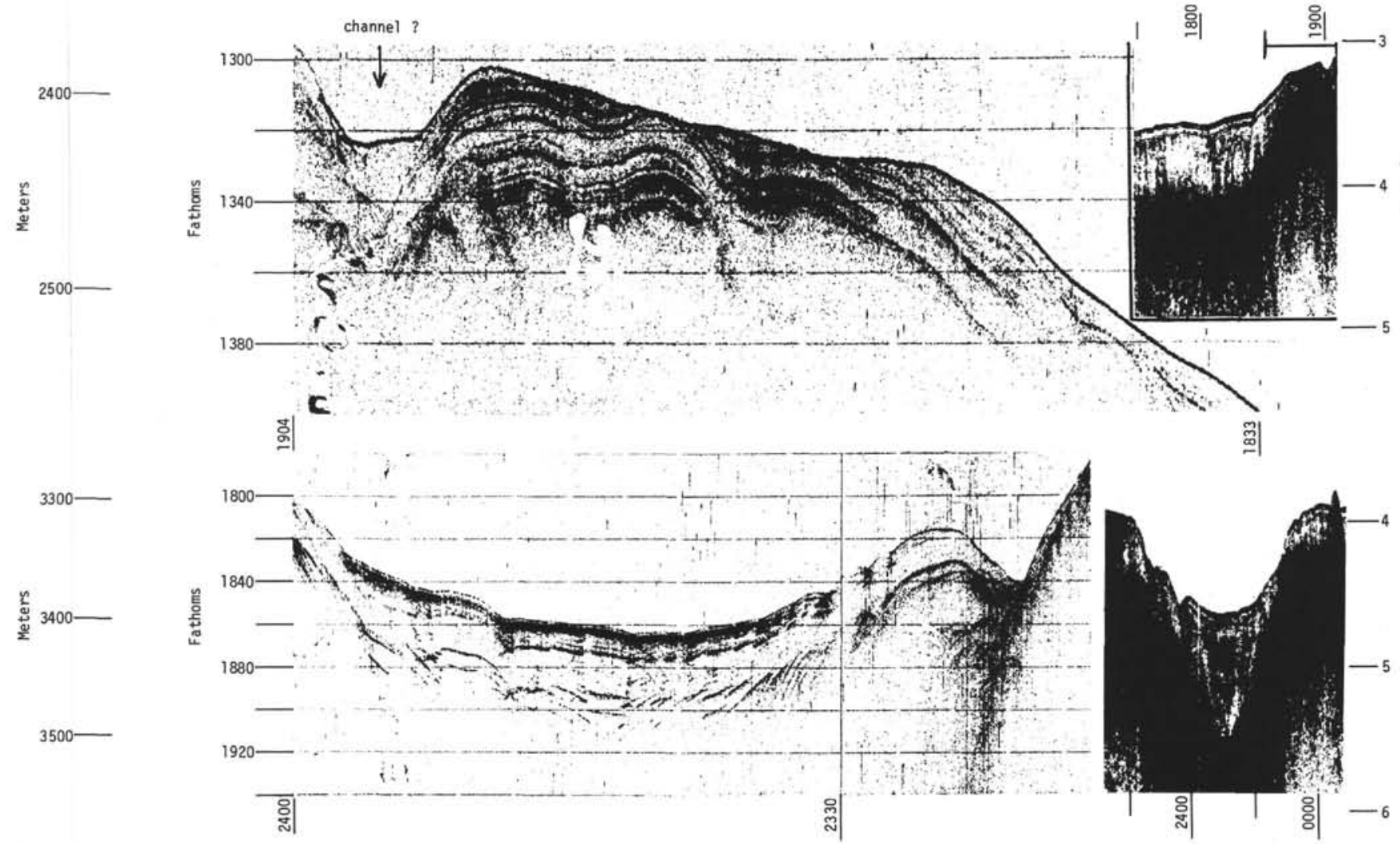

Figure 7. $3.5-\mathrm{kHz}$ fathograms and profiler sections (insets) on the Coiba Ridge. Top: A striking example of sediment removal by bottom currents along a major north-south trending fault scarp. See Figure 9 for location. Bottom: A cluster of very closely spaced faults extending to the surface, attesting to recent tectonic activity. Within a distance of less than $6 \mathrm{kms}$, at least ten offsets may be counted. This section was recorded along the southernmost track in the survey area just before the course change (Figure 2, also Profile 1098, Plate 1). 


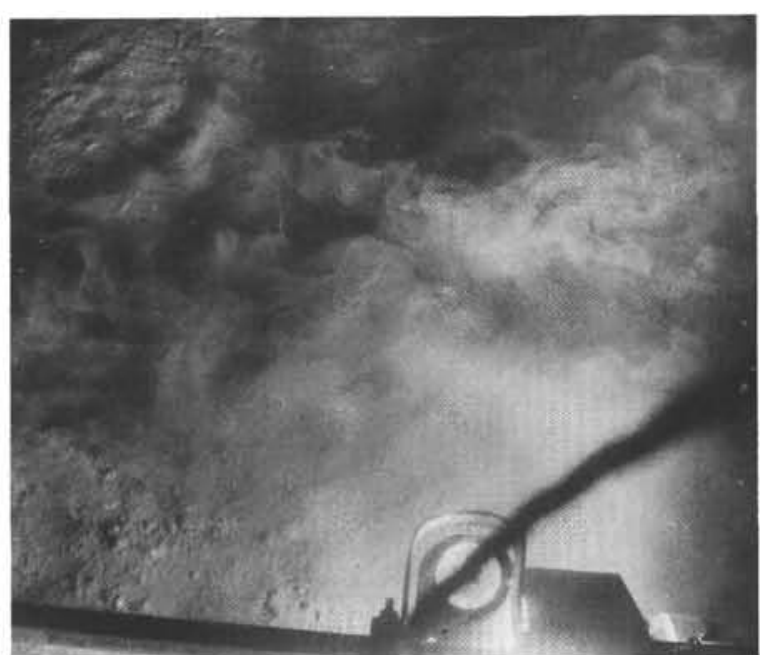

A

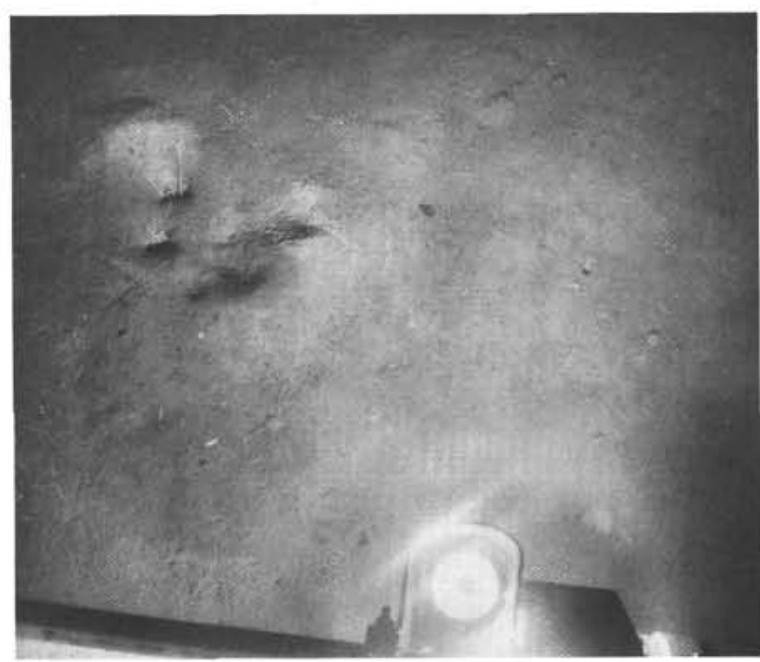

D

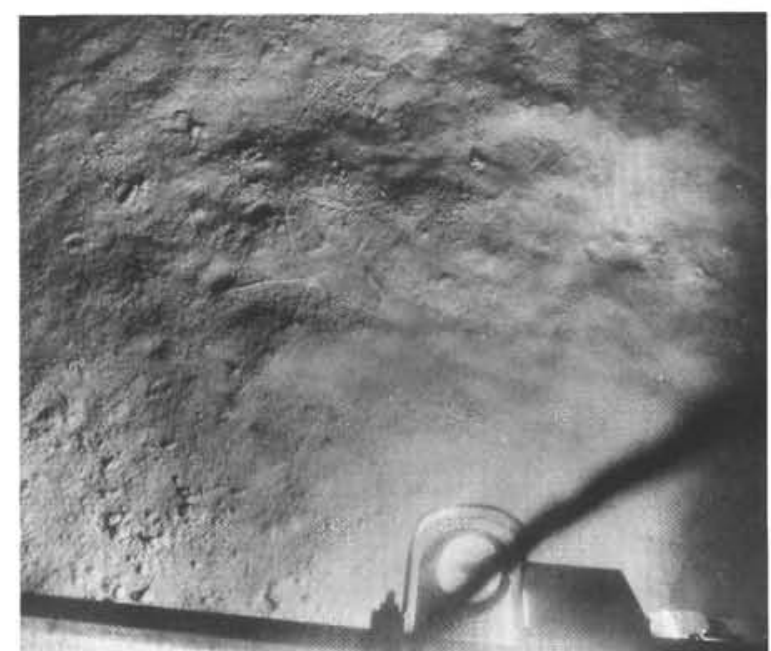

B

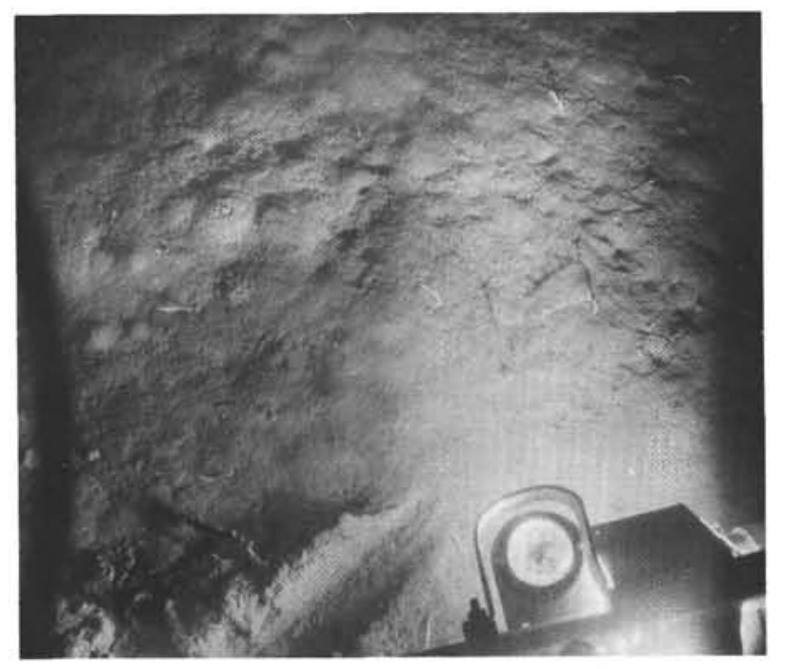

E

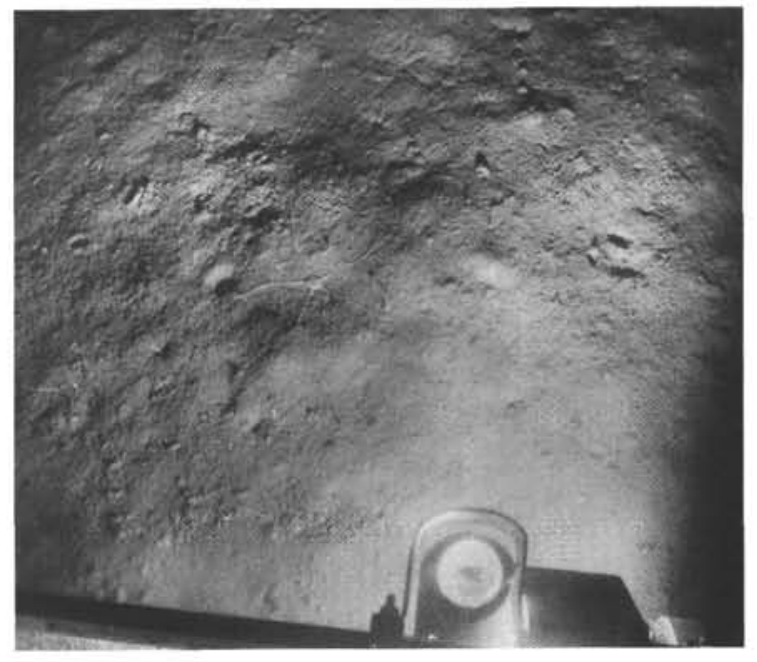

C

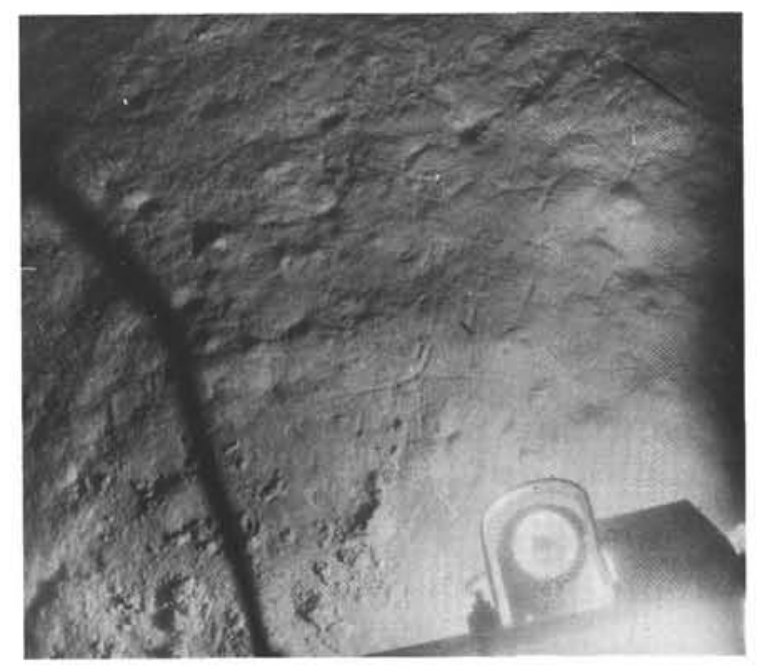

$\mathbf{F}$

Figure 8. Bottom photographs on the Cocos and Coiba ridges. A, B, C, and D were taken on Station 155 (Table 1) close to DSDP 158. The first two photographs were made about 60 seconds apart from a tripod sitting on the bottom. The passage of the mud cloud from left to right indicates the presence of a southwesterly flowing bottom current. Note the streaming effects in B. Frames $E$ and $F$ are from stations 148 (Profile 1095, Plage 1) and 150 (Profile 1111, Plate 1) respectively. Note that in Frame E most of the sea pens are bending with a southwesterly moving current. 
Figure 9 shows the seismic stratigraphy at the drill site, which is typical for most of the region with the exception of the acoustic basement, which is rather smooth here and more undulating elsewhere. Note that the smooth basement abuts the two peaks shown by the dashed line, as well as the large basement edifice on the right. A nearby sonobuoy station indicates that basement corresponds to the $4.20 \mathrm{~km} / \mathrm{sec}$ layer which overlies material with 5.18 $\mathrm{km} / \mathrm{sec}$ velocity (Figure 10). The lower most seismic unit probably corresponds to the Middle Miocene chalk recovered in DSDP 155. Note that this seismic horizon has vanished on the low-frequency channel. An important comment regarding the reflectivity characteristics of our profiles recorded on the Coiba Ridge is that the upper limit of our band pass filters was set at about $150 \mathrm{~Hz}$. This may be the reason why our profiles appear somewhat diffuse. More pronounced stratification would probably have appeared had we used higher frequencies, judging by the profiler section of Coiba Ridge shown by van Andel et al. (1971a) and in this volume (Chapter 2).

The above discussion implies that deposition on the Coiba Ridge has been current controlled. Indeed, the description of the acoustic section as diffuse, the presence of ripples (Ewing et al., 1971), and the evidence for bottom currents all bring to mind the sediment drifts discussed by Jones et al. (1970) and Le Pichon et al. (1971). The sediment cover on the Coiba Ridge is different, however, in that it conforms to basement relief while current-controlled deposits do not. The presence of "ripples" here is real, suggesting some sort of controlled deposition. But, since we cannot trace them beyond the top seismic horizon near the surface (Figure 9), the regime responsible for their formation represents only a brief span of geologic time and hence does not bear on the problem of the whereabouts of the Coiba Ridge in the more distant past, in the context of the Panama Basin evolution as postulated by van Andel et al. (1971a).

\section{COIBA FRACTURE ZONE}

Separating the two ridges is the Coiba Fracture Zone (Figure 11; see Figure 1 for location). The uplifted sediments along the central portion of the section and the evidence for recent movements shown on the fathogram represent a striking confirmation of the intense seismic activity in this region (van Andel et al., 1971a, p. 1496).

Of special interest is the region between 0800 and 0940 hours. Sediments of this type (lack of coherent subbottom reflections and small-scale topographic roughness) have been observed along subduction zones (Ewing et al., 1967; Collette et al., 1969). These characteristics are now generally believed to be the result of intense deformation produced by underthrusting (see review in Hayes and Ewing, 1970 or Chase and Bunce, 1969). Thus, these data represent a measure of support for the idea of a "plugged-up" trench here, as postulated by van Andel et al. (1971a).

\section{COCOS RIDGE (DSDP 158)}

The crustal portion of the ridge delineated by our survey is, on the whole, considerably more varied and complex than the Coiba site with regard to its topography
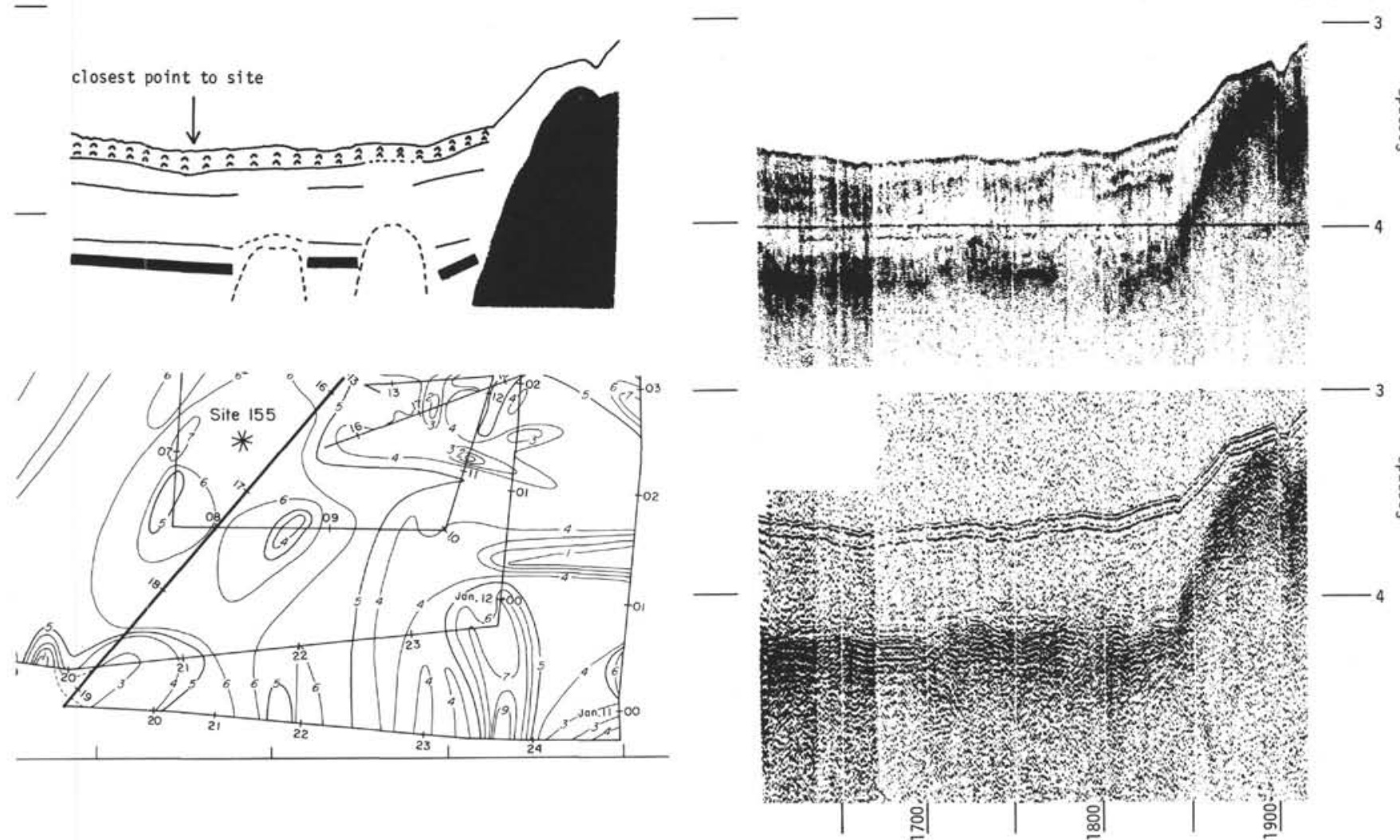

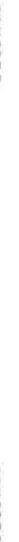

Figure 9. Coiba Ridge. High-and low frequency channel profiler records near the drill site and a line interpretation showing typical seismic stratigraphy for the region. The symbols within the top unit denote the subbottom continuation of the "rippled" sea floor. 

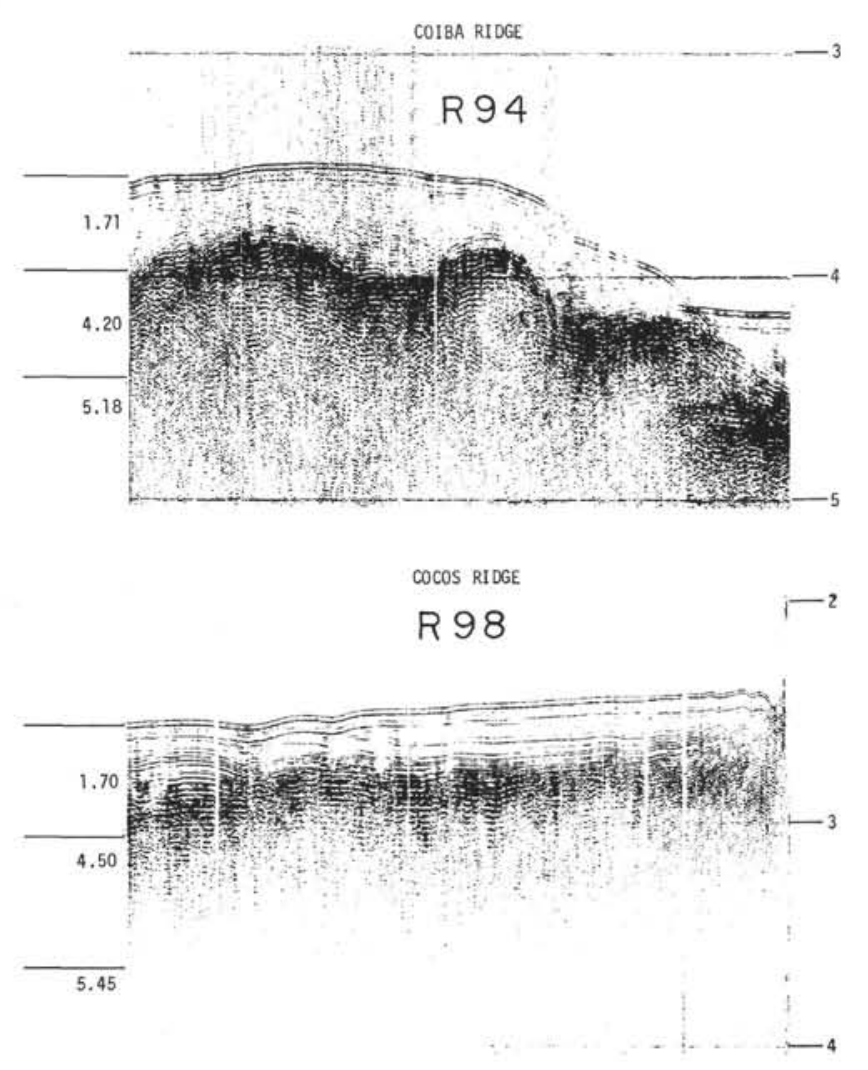

COCOS RIOGE

R 100

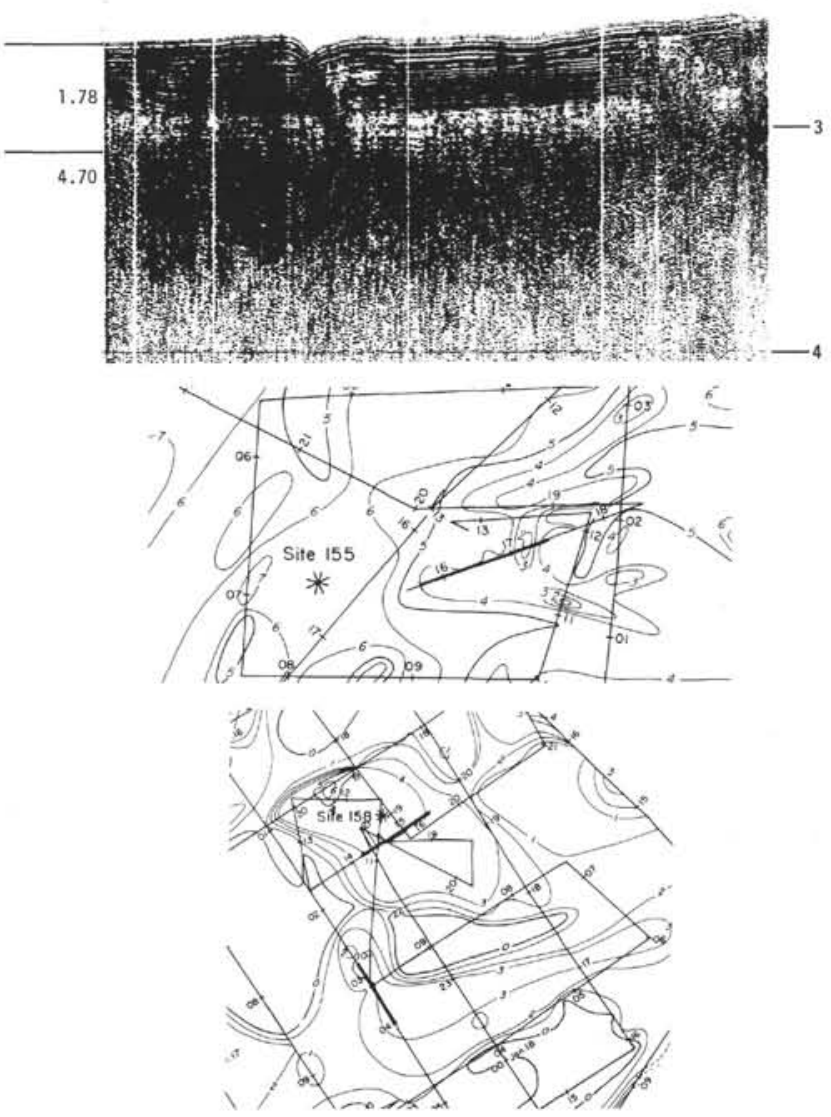

Figure 10. Vertical reflection profiles shown with their velocity structures determined from simultaneously shot sonobuoys R94 (Profile 1112, Plate 1), R98 (Profile 1137, Plate 3), and R100 (Profile 1148, Plate 3) which runs within the tary basin where the drill site lies. Their respective locations are: $06^{\circ} 09.8^{\prime} \mathrm{N}, 80^{\circ} 53.6^{\prime} \mathrm{W} ; 06^{\circ} 24.1^{\prime} \mathrm{N}, 85^{\circ} 16.6^{\prime} \mathrm{W} ; 06^{\circ} 33.0^{\prime} \mathrm{N}$, $85^{\circ} 16.9^{\prime} \mathrm{W}$. The velocities in the unconsolidated sediments were determined from wide-angle reflections. On profile R100, the transparent layer beneath the stratified sequence is spurious and a result of amplifier overloading. Note the internal stratification of the acoustic basement in all the profiles, even where it has an undulating character (R94).

(Figure 12), pattern of sediment distribution (Figure 13), sea floor morphology, and structures within the sediment cover. The region is dominated by basement ridges which divide the area into isolated sedimentary basins having similar stratigraphy and surface morphology. The drill site lies in one such basin, this basin having the thickest sediment section in the area.

A seismic reflection profile across this isolated basin, recorded while approaching the site from the Guatemala Basin across a prominent northeast-southwest trending ridge, is shown in Figure 14. The seismic stratigraphy consists of an upper, relatively transparent layer containing faint and somewhat widely spaced reflectors which overlies a distinctly stratified sequence consisting of two zones, each marked by a fairly strong reflector, the lowermost zone having more closely spaced and stronger reflecting horizons. The thickness of the top unit ranges from 0.10 to $0.16 \mathrm{sec}$ and from $0.20-0.27$ second for the lowermost unit which corresponds to the Miocene chalk recovered in DSDP 158. The basin is floored by a relatively smooth acoustic basement which, closer scrutiny, reveals very fine corrugations that are repeated in the lower stratified unit. A sonobuoy station nearby shows that this basement corresponds to a $4.20 \mathrm{~km} / \mathrm{sec}$ layer (Figure 10). Sonobuoy R98, located in an adjacent basin, shows the presence of two layers similar to those shown by sonobuoy R94 on the Coiba Ridge. The depth to acoustic basement on our profiler section (Figure 14) ranges from 0.35 to $0.41 \mathrm{sec}$ reflection time.

The sea floor morphology of the drilled basin (Figure 14) consists of a variety of features which appear to be of mixed origins, a situation found throughout the site survey. For example, the depression at 1915 hours is clearly a product of erosion. Note that the base of the top transparent layer here appears to unconformably overlie the stratified sequence. Bottom photographs obtained nearby 


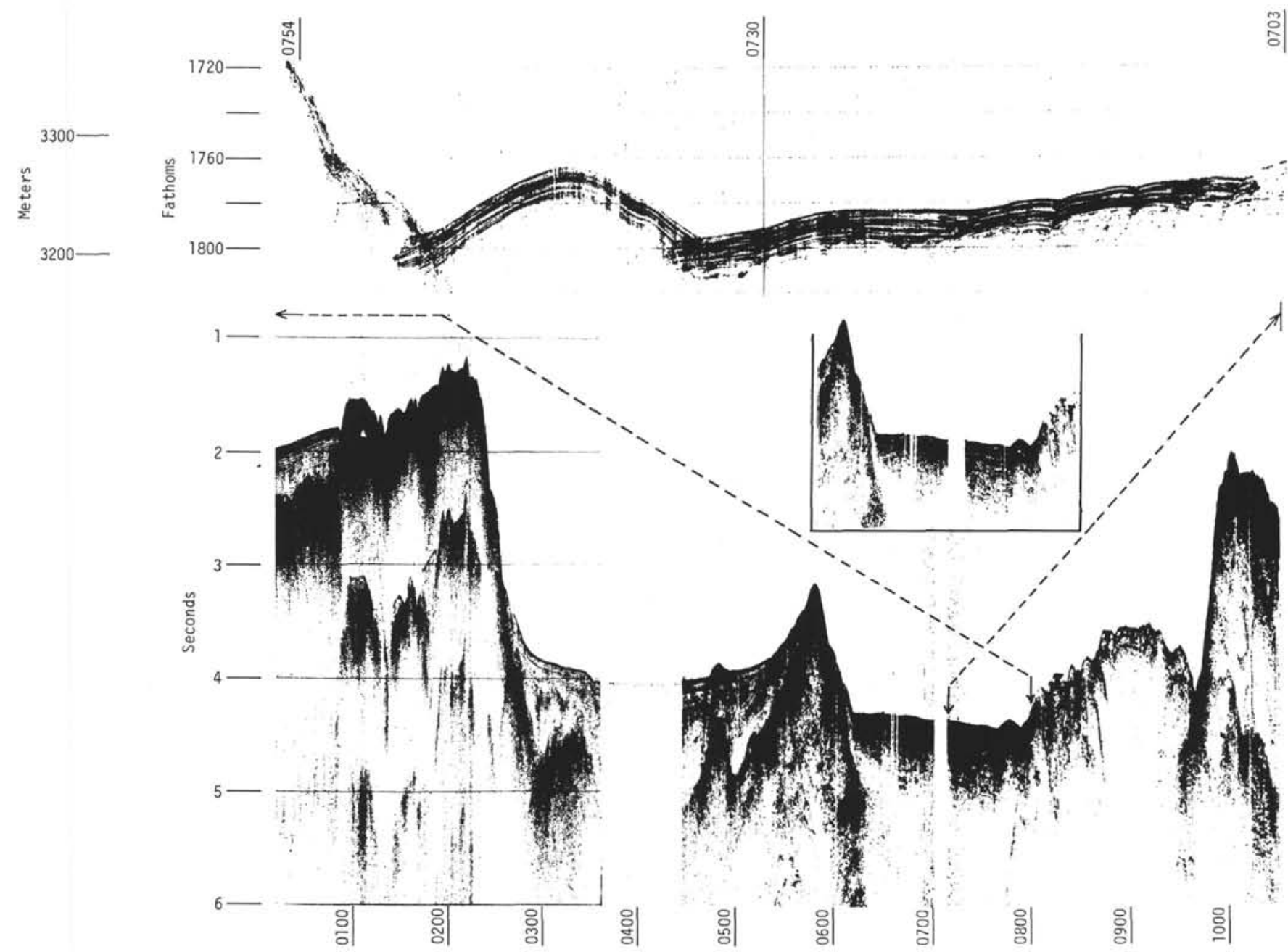

Figure 11. Coiba Fracture Zone bounded by the western face of the Coiba Ridge on the left and the eastern edge of Cocos Ridge on the right. The $3.5-\mathrm{kHz}$ fathogram shows the presence of numerous faults and a fold with an apparently fractured apex, attesting to recent tectonic activity.

(Station 155, Figure 8) show evidence for the existence of a bottom current competent to at least move a mud cloud across the camera's field of view. The central valley is a rather enigmatic feature. Wilde (1966) has observed similar cross sections on fathograms on Cocos Ridge and postulated that these may be channels formed by local ash-laden turbidity currents. This feature cannot be explained by erosion, however, since the subbottom horizons continue into the valley floor. A channel-like cross section showing a striking confirmation of erosion has been found on Cocos Ridge, but it is located closer to land, north of the survey area (Figure 21). A third type of surface irregularity is the "ripple" at 1830 hours which may be the surface expression of a growth fault. Note that it is underlain by a thin, vertical zone of confused reflectivity, one of the criteria listed by van Andel et al. (1971a) for inferring faults on seismic profiles. Furthermore, there is a depth difference across it.

The southeastern boundary of the drilled basin is shown in Figure 15. Note that the smooth basement abuts the ridge, which narrows to the northeast. A profile recorded along a track across its tip (Profile 1133, Plate 2) reveals a narrow peak. Some of these pinnacles are apparently of volcanic origin (Figure 16). The sediment cover shown in Figure 15 reveals a diversity of features similar to the profile near the site. On the $3.5-\mathrm{kHz}$ fathograms along this section, stretches of near-surface unconformities are apparent. This section also contains the best example of a fault in the area, corresponding to the 1940-hour location (see Figure 17).

With regard to faulting, a curious feature about the drilled basin is that the stratified sequence terminates abruptly along a vertical line (Figure 19, $0000 \mathrm{hrs}$. A similar situation is apparent along its northeastern boundary (Figure 18, $1730 \mathrm{hrs}$.). Our original interpretation was that the basin is bounded by faults predating the deposition of the stratified sequence, since the horizons are not bent at the contact. This did not account, however, for the absence of the stratified sequence between the ridge and the presumed fault. We then reexamined the data and noted that it is possible to discern the continuation of the basement and the strata into the opaque section. Figure 19 shows that a highly reflective near-surface horizon is capable of masking basement, giving an illusion of a fault. A 


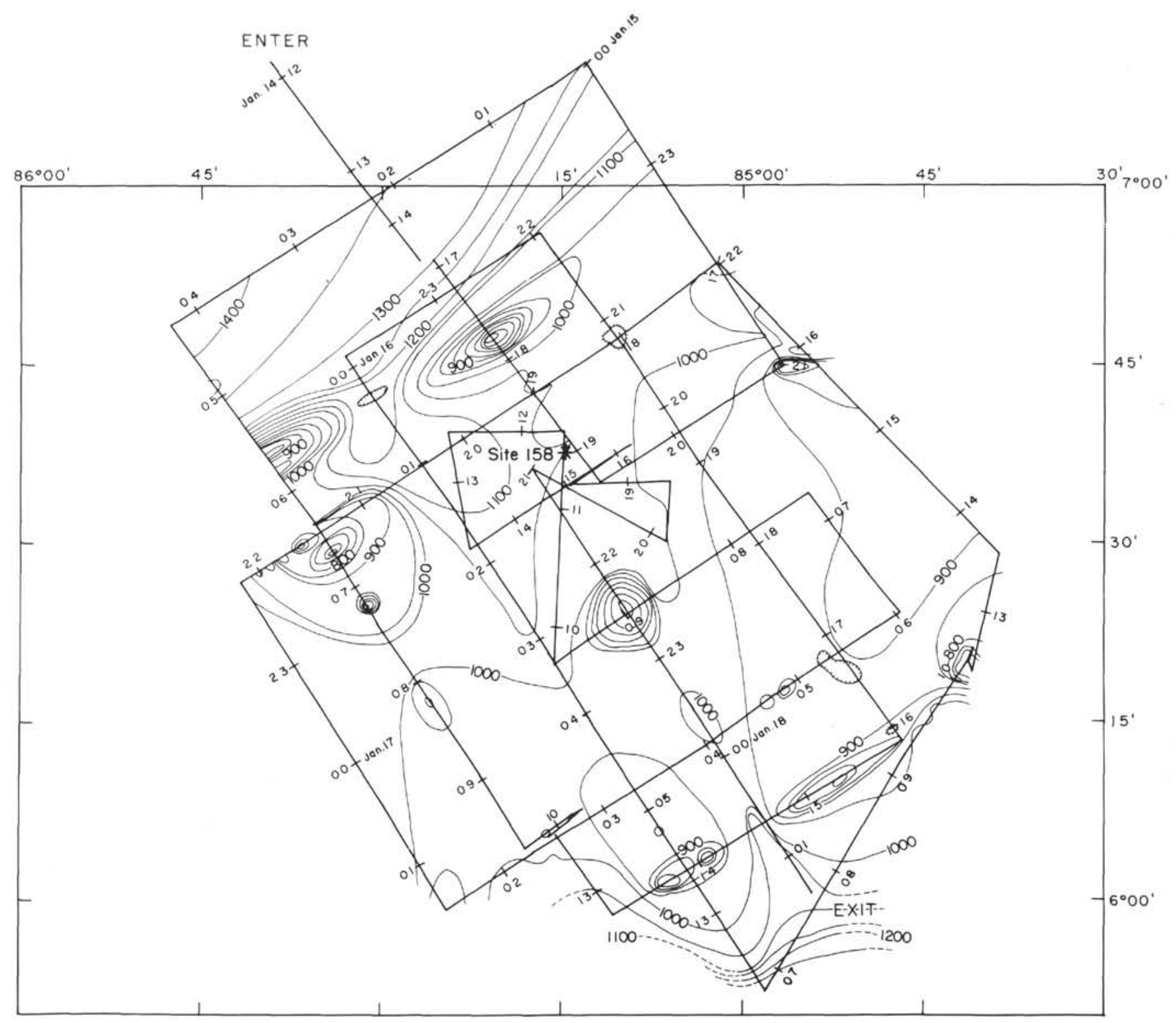

Figure 12. Bathymetric map of Site DSDP 158 survey contontoured in nominal fathoms at a 50-fm contour interval.

total eclipse of basement caused by a strongly reflective layer has been observed before, for example in the Madagascar Basin (Ewing and Ewing, 1970, Fig. 28) where the layer in question is a turbidite. On Cocos Ridge, the horizon could be a sill (as is frequently the case near a ridge) or an interface produced by bottom currents which have been associated with zones of high reflectivity (Le Pichon et al., 1971).

The important role of bottom currents on some parts of Cocos Ridge is apparent from Figure 20 which shows only a remnant of a sedimentary cover. Core 135 has been dated by T. Saito (personal communication) as Middle Pliocene at the bottom. Furthermore, he found a "...... hiatus whereby the Middle Pliocene sediments are disconformably overlain by Middle Pleistocene sediments" (T. Saito personal communication).
The effect of bottom currents in the sedimentary basins, however, appears to be superficial, but their presence does tend to bias our opinion regarding the origin of most of the surface irregularities in the area in favor of tectonism. That is, we envision small-scale topographic features originally created by faulting, becoming more accentuated by preferential erosion by bottom currents (Johnson, 1971).

\section{ACKNOWLEDGMENTS}

This work has been supported by National Science Foundation Grant GA 28338. We have benefited from discussions with George Carpenter, Stephen Eittreim, Robert Embley, Olav Eldholm, John Ewing, and Bruce Heezen. Special thanks go to Tsunemasa Saito for his analysis of the V28-135 core. We are also grateful to Maurice Ewing for granting permission to publish the bottom photographs. 


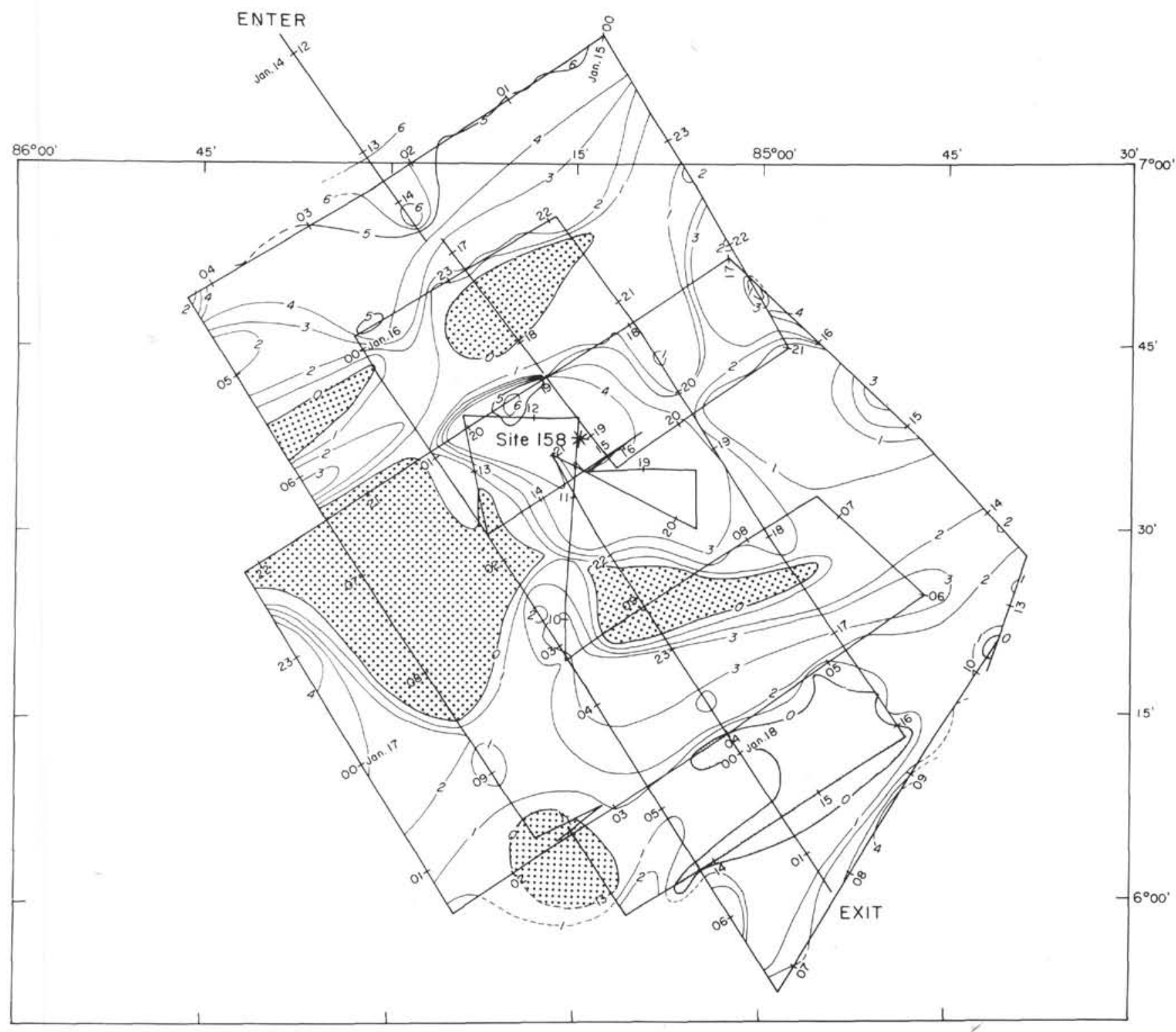

Figure 13. Sediment thickness map of Site DSDP 158 survey contoured in tenths of seconds of two-way reflection time. The map is based on reflection time readings at 10-minute intervals. This region is covered by Profiles $1125-1151$ (Plates 2 and 3). Stippled: basement outcrop. 


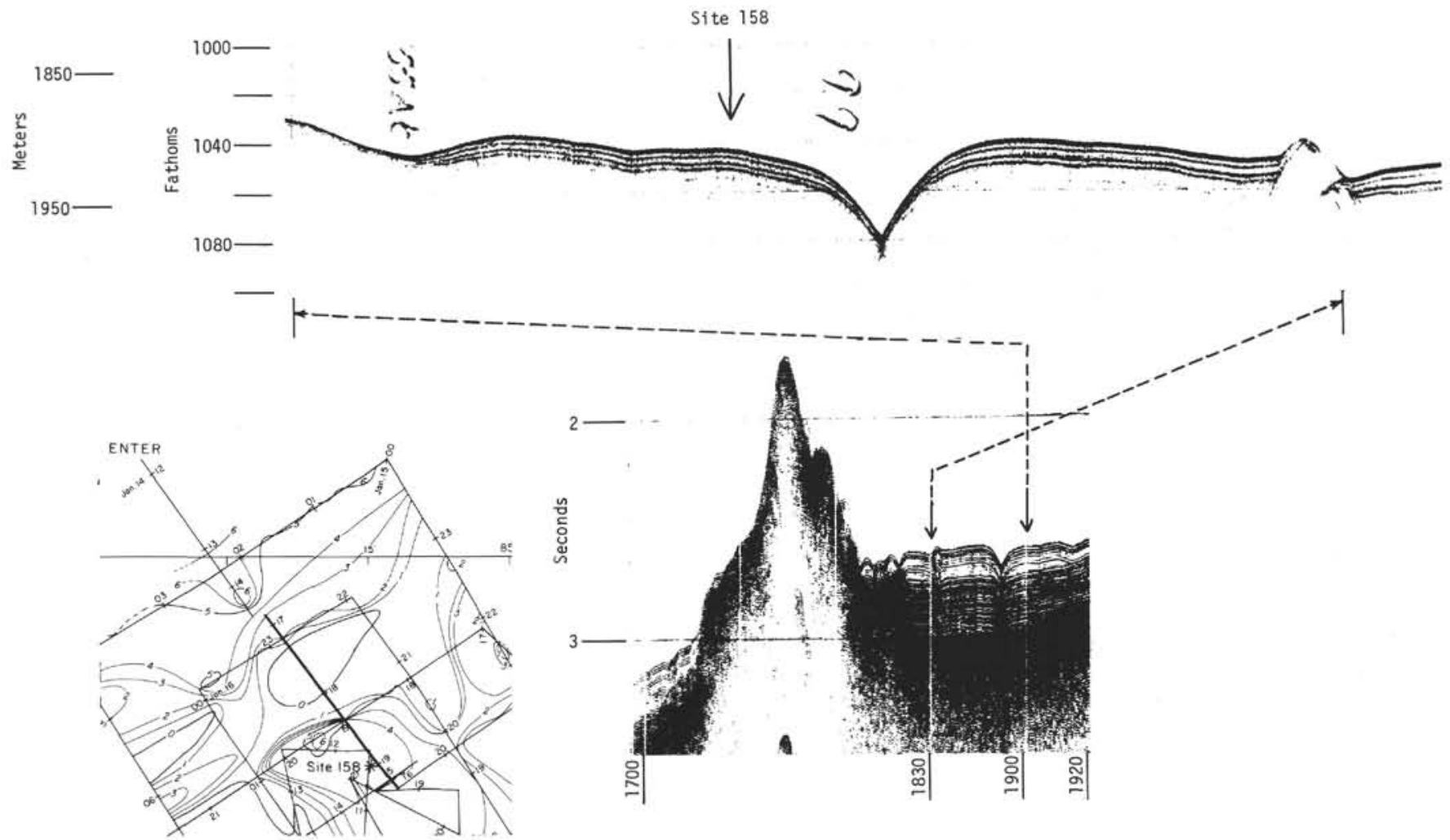

Figure 14. Cocos Ridge. A seismic reflection and 3.5-kHz fathogram near DSDP 158.
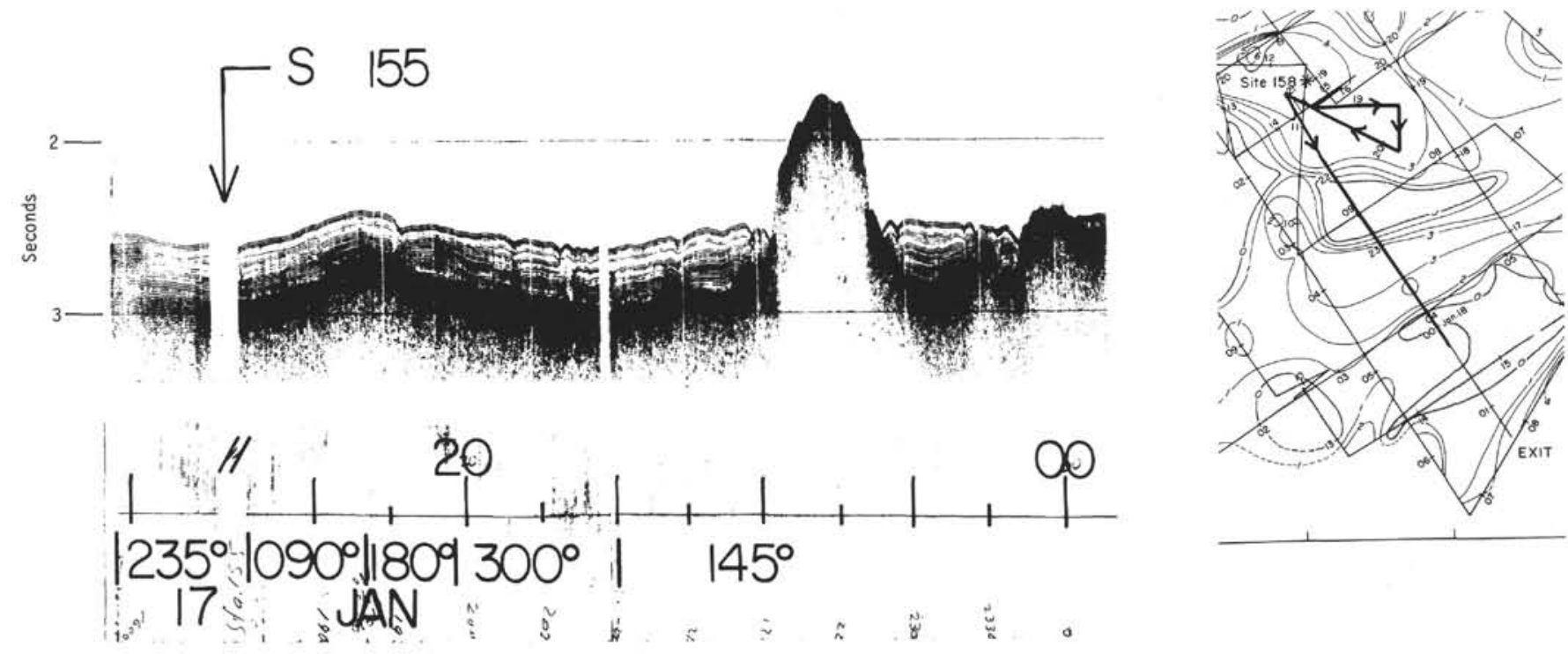

Figure 15. Seismic reflection profile recorded during the last 8 hours in the survey area showing the southeastern boundary of the basin on which the drill site lies. 

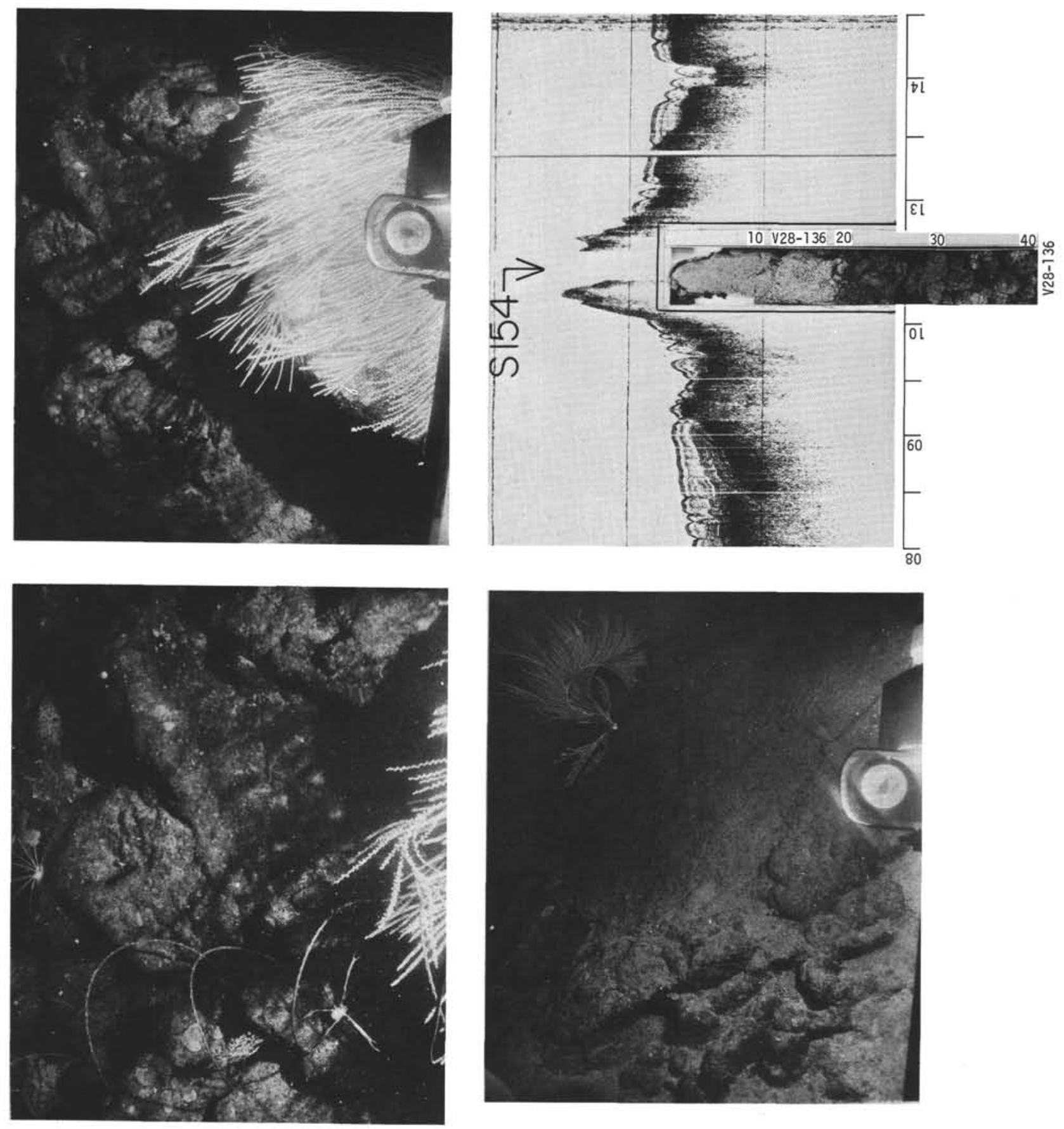

Figure 16. Cocos Ridge. Bottom photographs and a 42-cm piston core from R.V. Vema 28, Station 154 occupied near the easternmost corner of the survey (Figures 12 and 13). The photographs show volcanic rocks somewhat pillowy in character, gorgonians, a sea urchin, and a crustacean in confrontation with the spiraling hydro wire. The piston core consists of $19 \mathrm{~cm}$ of foraminiferal ooze overlying volcanic sand and weathered volcanic gravel. The seismic reflection section is covered by Profiles 1139 and 1140 (Plate 3). The smooth acoustic basement containing hints of stratification exhibits a pronounced normal fault on the left of the central peak and a graben on the right. The acoustic section above the faulted basement retains the same character as Figure 14 near the drill site, consisting of an upper semitransparent layer overlying a distinctly stratified one. Observe the thinning of the top layer onto the rising basement. 


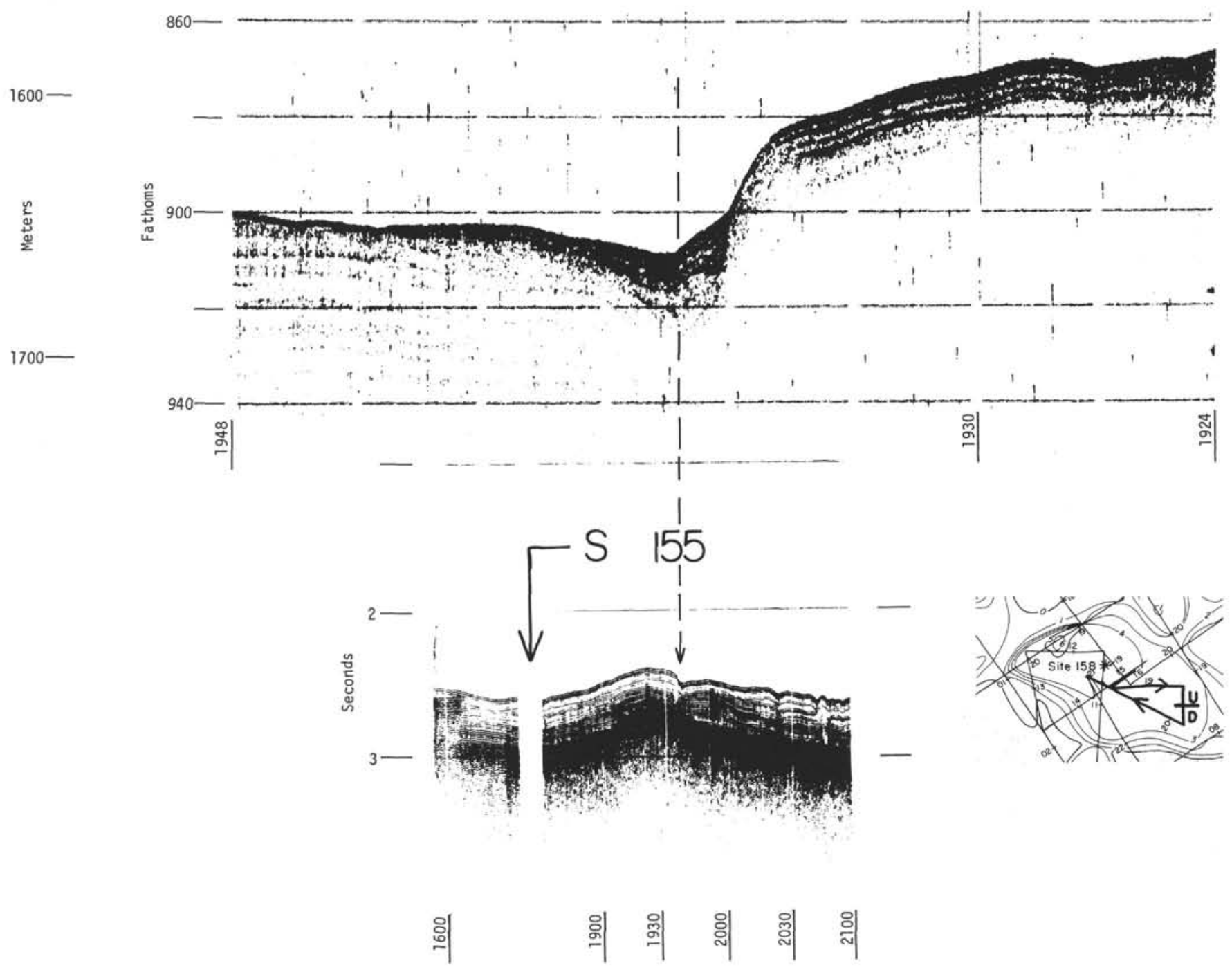

Figure 17. Cocos Ridge. Seismic Relfection and 3.5-kHz profile across a fault. The acoustic section consists of an upper semitransparent layer overlying a stratified one. Note the smoothness of the acoustic basement. Note the striking evidence for the presence of bottom currents which have apparently removed the three strong subbottom reflectors on the down side of the fault. 


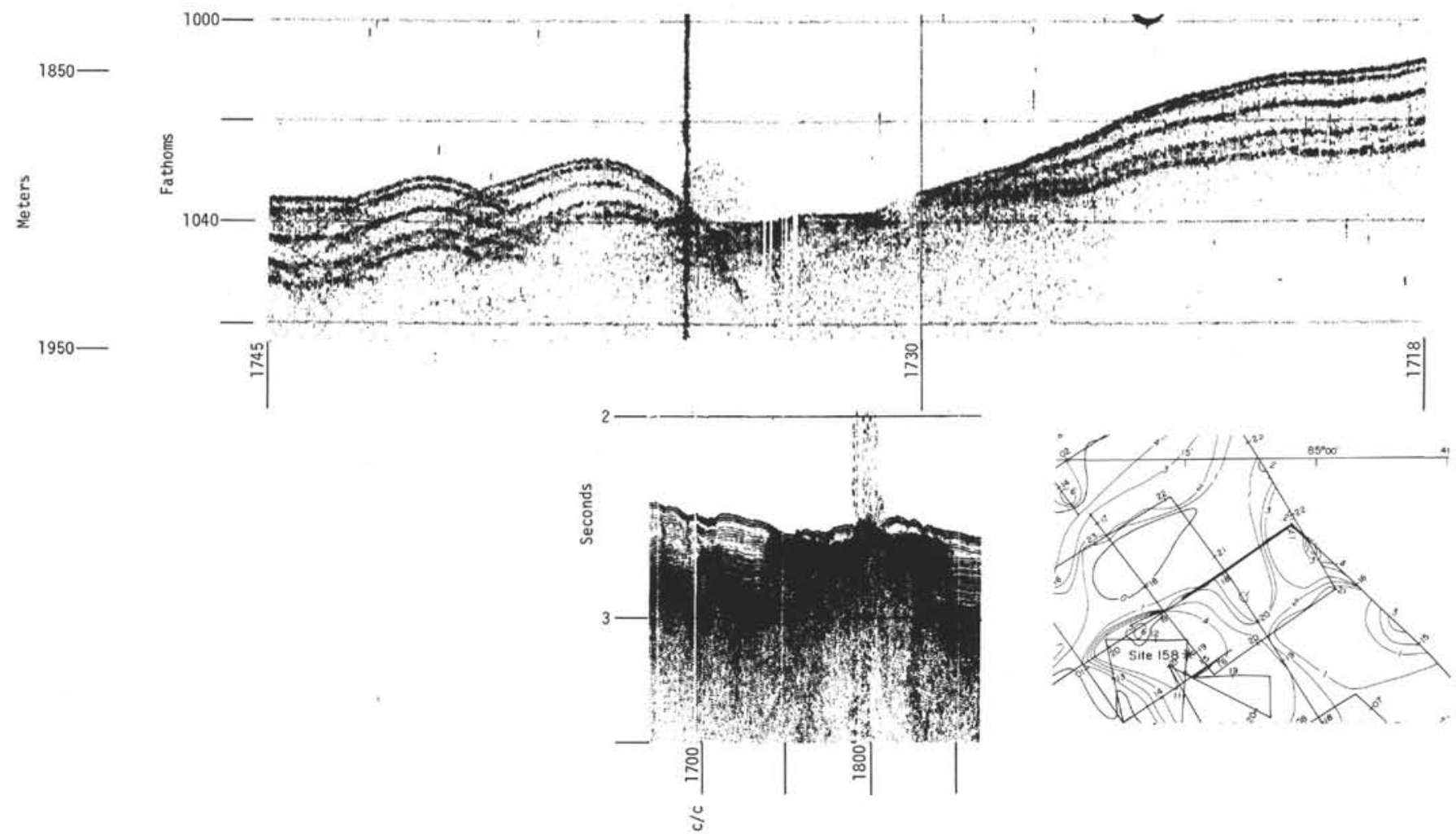

Figure 18. Cocos Ridge. A 3.5- $\mathrm{kHz}$ and seismic reflection profile showing erosion by bottom currents and an "eclipse" of the acoustic basement caused by a highly reflective zone near the sea floor. Note that the smooth basement and the lower portion of the stratified sequence can both be followed for some distance beneath the "roof" of the opaque section /1730 and $1830 \mathrm{hrs}$. I from both sides. 

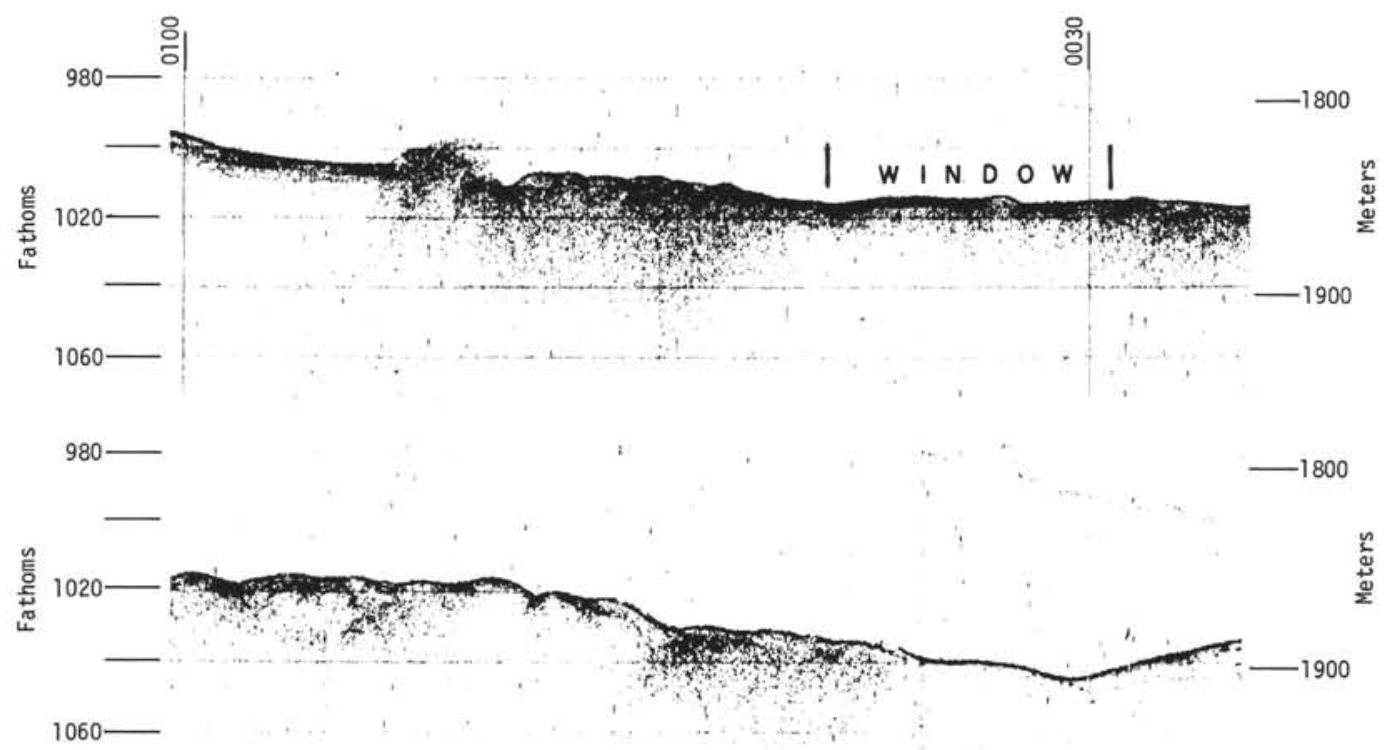

잉|

잉

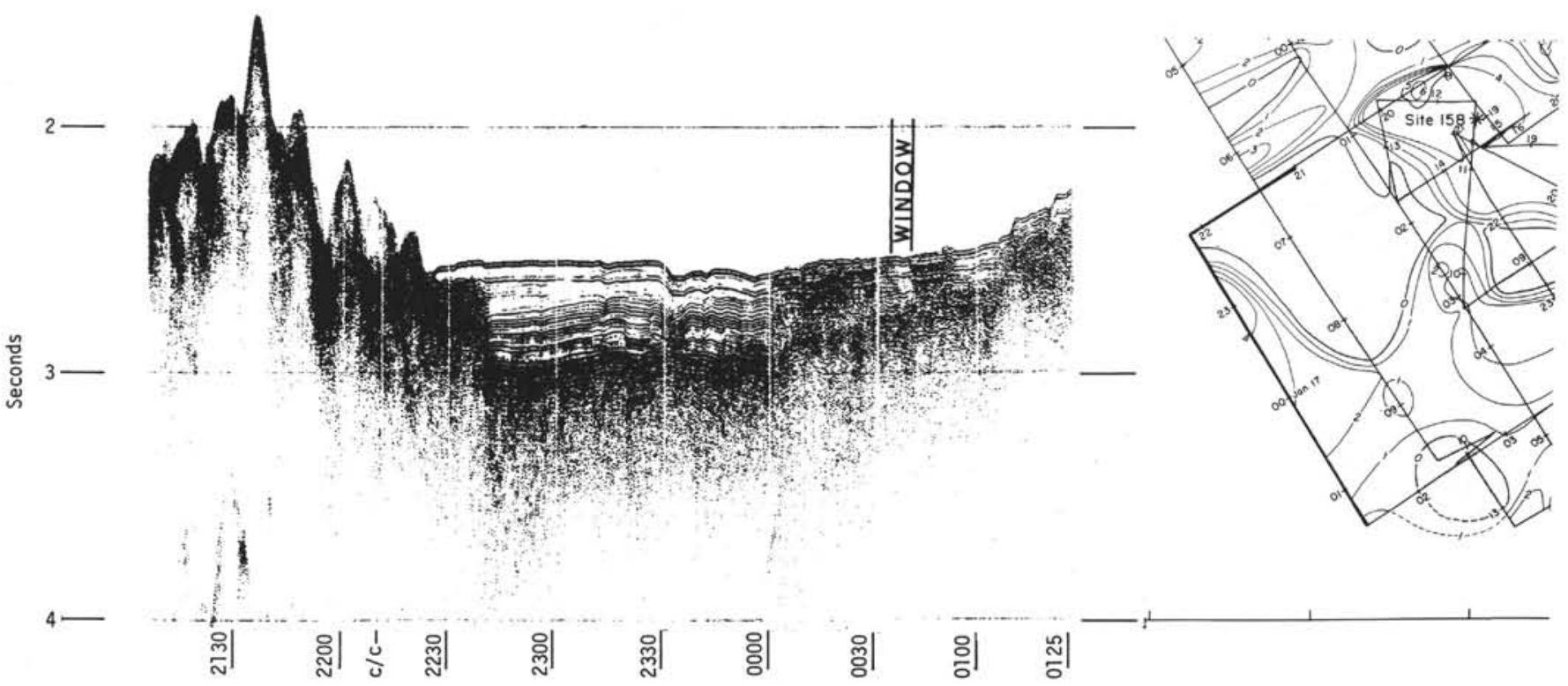

Figure 19. Cocos Ridge. A 3.5-kHz and seismic reflection profile across a basin adjacent to the drill site. Note the similarity between the seismic stratigraphy shown here and the section across the drilled basin (Figure 14) and also the apparent abrupt termination of the lower stratified unit near the basement ridge in both. The figure serves to illustrate the excellent correlation between stretches of high reflectivity on the profiler record with stretches of sea floor characterized by small-scale roughness. The continuation of the acoustic basement beneath the highly reflective bottom may be discerned and is clearly seen through the window of the smooth sea floor. 

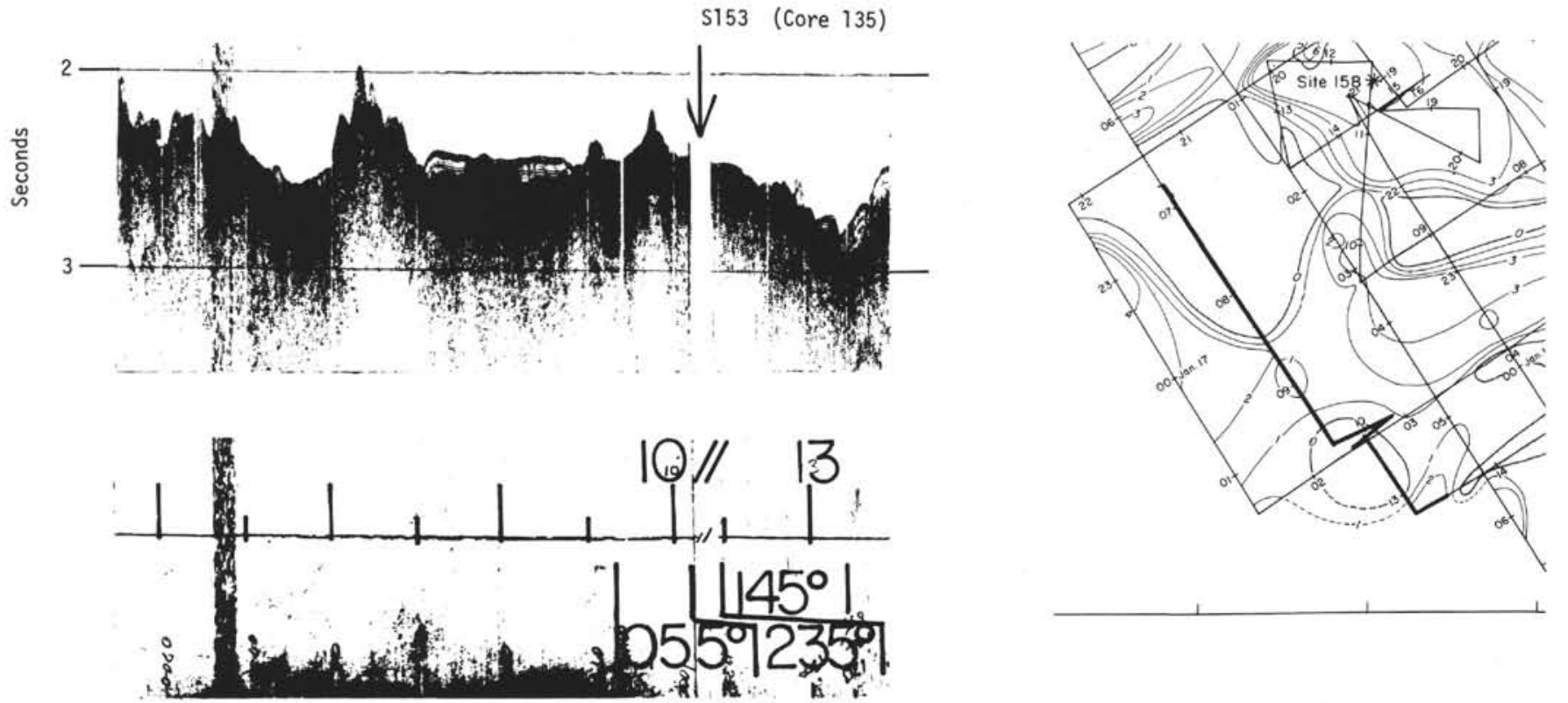

Figure 20. Cocos Ridge. Seismic reflection profile with the location of piston core V28-135 of Middle Pliocene age. The highly reflective portion of the thin sedimentary cover, centered at 0900 hours, probably correlates with similar zones on the adjacent, southeasternmost tract (Figure 19).

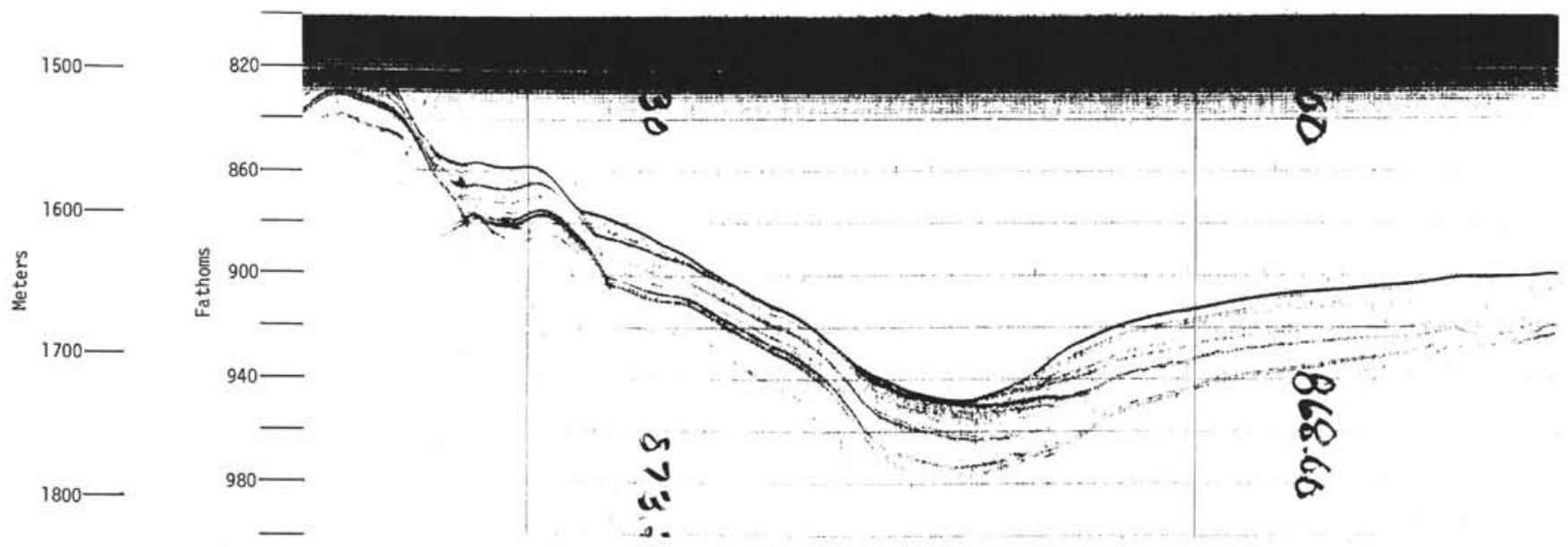

Figure 21 Cocos Ridge. A 3.5-kHa fathogram of an erosional channel recorded along the east-west traverse of Cocos Ridge north of the site survey (Figure 1). The section lies just west of the Coiba Fracture Zone between 1544 and 1640 hours along the ship's track in Figure 1. This record corresponds to Profile 1118, Plate 2. 


\section{REFERENCES}

Chase, R.L. and Bunce, E.T., 1969. Underthrusting of the eastern margin of the Antilles by the floor of the western North Atlantic, and origin of the Barbados Ridge. J. Geophys. Res. 74 (6), 1413.

Collette, B.J., Ewing, J.I., Lagaay, R.A. and Truchan, M., 1969. Sediment distribution in the oceans: The Atlantic between $10^{\circ}$ and $19^{\circ} \mathrm{N}$. Marine Geol.7, 279.

Ewing, J. and Ewing, M., 1970. Seismic reflection. In The Sea. Maxwell, A.E. (Ed.). New York (Wiley) 4, 1.

Ewing, J., Talwani, M., Ewing, M. and Edgar, T., 1967. Sediments of the Caribbean. In Proc. Intern. Conf. Tropical Oceanog. Univ. Miami, Miami; Florida. 88.

Ewing, M., Eittreim, S., Ewing, J. and Le Pichon, X., 1971. Sediment transport and distribution in the Argentine Basin: Part 3, Nepheloid layer and processes of sedimentation. In Physics and Chemistry of the Earth. Ahrens, L.H., Press, F., Runcorn, S.K. and Urey, H.C. (Eds.). Oxford (Pergamon Press), 7.

Hayes, D.E. and Ewing, M., 1970. Pacific boundary structure. In The Sea. Maxwell, A.E. (Ed.). New York (Wiley) 4, 1.
Johnson, D.A., 1971. Studies of deep-sea erosion using deeptowed instrumentation. Ph.D. dissertation, Univ. California, San Diego. 170.

Jones, E.J.W., Ewing, M., Ewing, J. and Eittreim, S.L., 1970. Influence of Norwegian Sea water on sedimentation in the northern North Atlantic and Labrador Sea. J. Geophys. Res. 75 (9), 1655.

Le Pichon, X., Eittreim, S. and Ewing, J., 1971. A sedimentary channel along Gibbs Fracture Zone. J. Geophys. Res. 76 (12), 2891.

Thorndike, E.M. and Ewing, M., 1969. Photographic determination of ocean-bottom current velocity. Marine Tech. J. 3, 45.

van Andel, Tj.H., Heath, G.R., Malfait, B.T., Heinrichs, D.F. and Ewing, J., 1971a. Tectonics of the Panama Basin, eastern equatorial Pacific. Bull. Geol. Soc. Am. 82, 1489.

van Andel, Tj.H., Heath, G.R., Bennett, H., Charleston, S., Cronan, D.S., Rodolfo, K.S., Yeats, R.S., Bukry, D., Dinkelman, M. and Kaneps, A., 1971b. Deep Sea Drilling Project: Leg 16. Geotimes. 16 (6), 12.

Wilde, P., 1966. Quantitative measurements of deep-sea channels on the Cocos Ridge, east central Pacific. Deep-Sea Res. 13, 635 . 


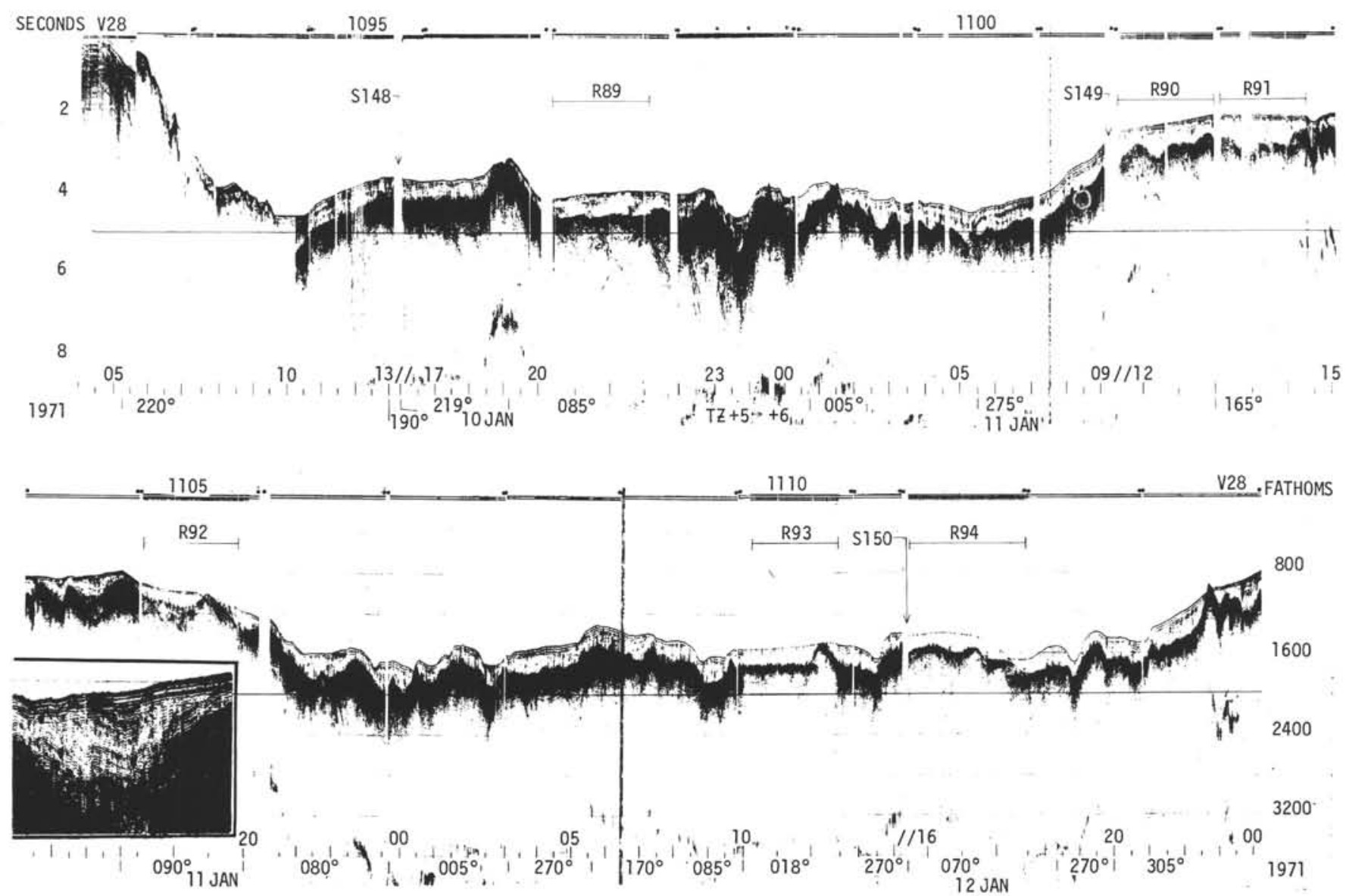

Plate 1. Seismic reflection profiles recorded by the R. V. Vema during Site DSDP 155 survey. The inset contains an enlarged portion of Profile 1104 showing an eroded synclinal structure. 


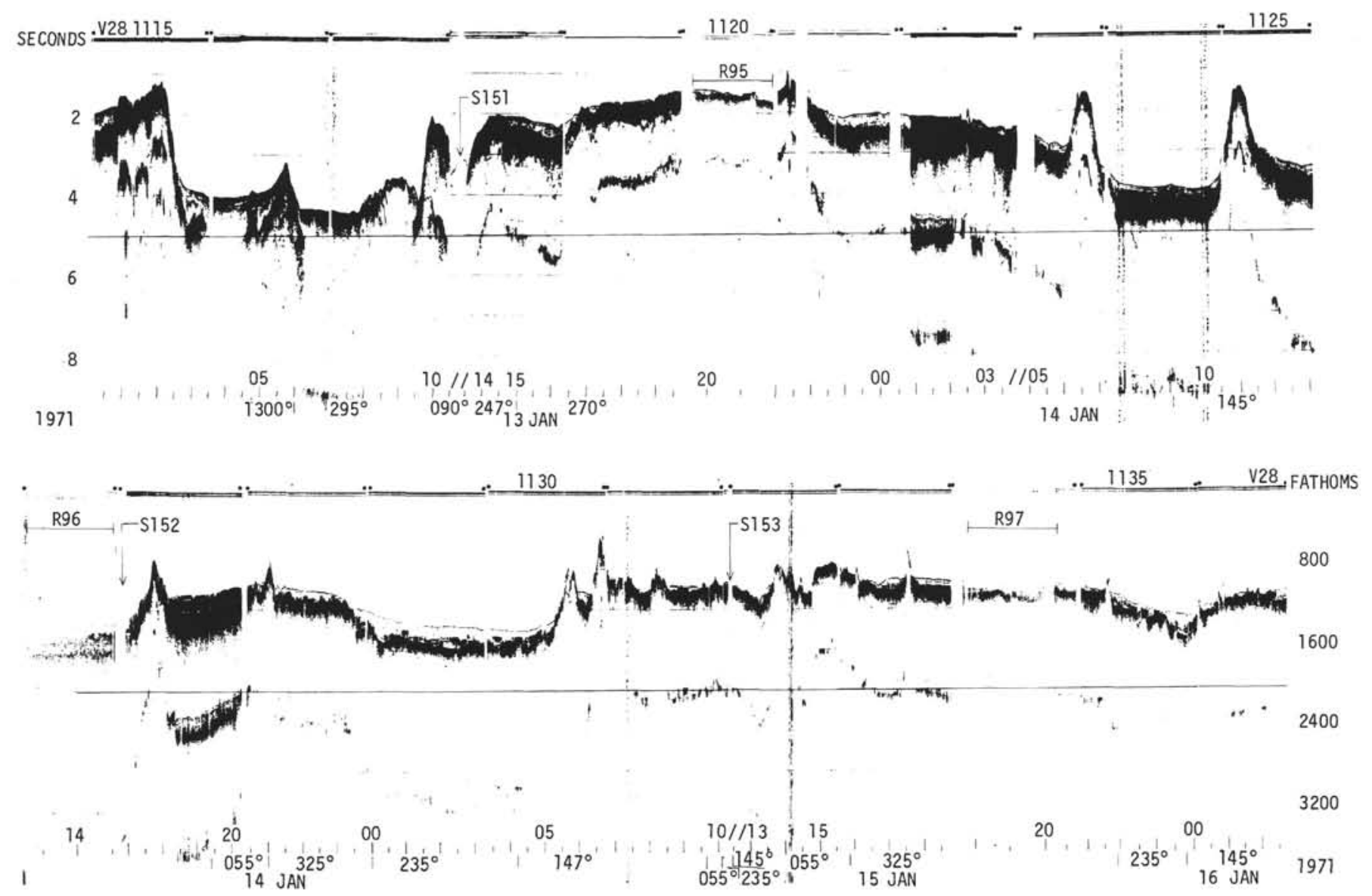

Plate 2. Seismic reflection profiles recorded by the R. V. Vema during Site DSDP 158 survey. Profiles $1115-1117$ cover the Coiba Fracture Zone. 


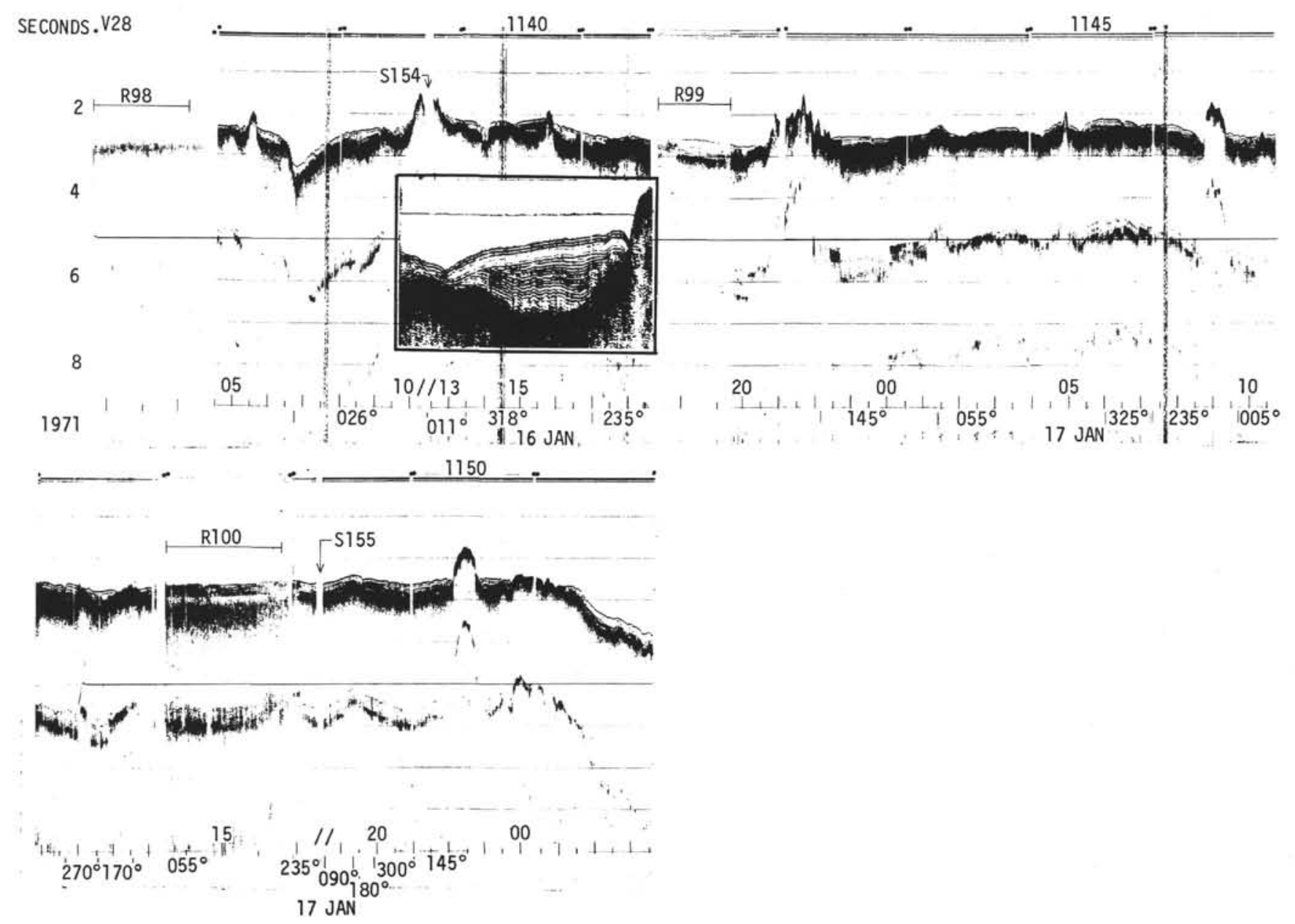

Plate 3. Seismic reflection profiles recorded by the R. V. Vema during Site DSDP 158 survey. The enlarged portion of Profile 1140 shows an eroded synclinal structure. 